\title{
THE REPRODUCTION AND LARVAL DEVELOP- MENT OF NEREIS DIVERSICOLOR O. F. MÜLLER
}

\author{
By R. Phillips Dales, B.Sc., Ph.D. \\ From the Department of Zoology, Queen Mary College, University of London
}

(Plate I and Text-figs. I-I3)

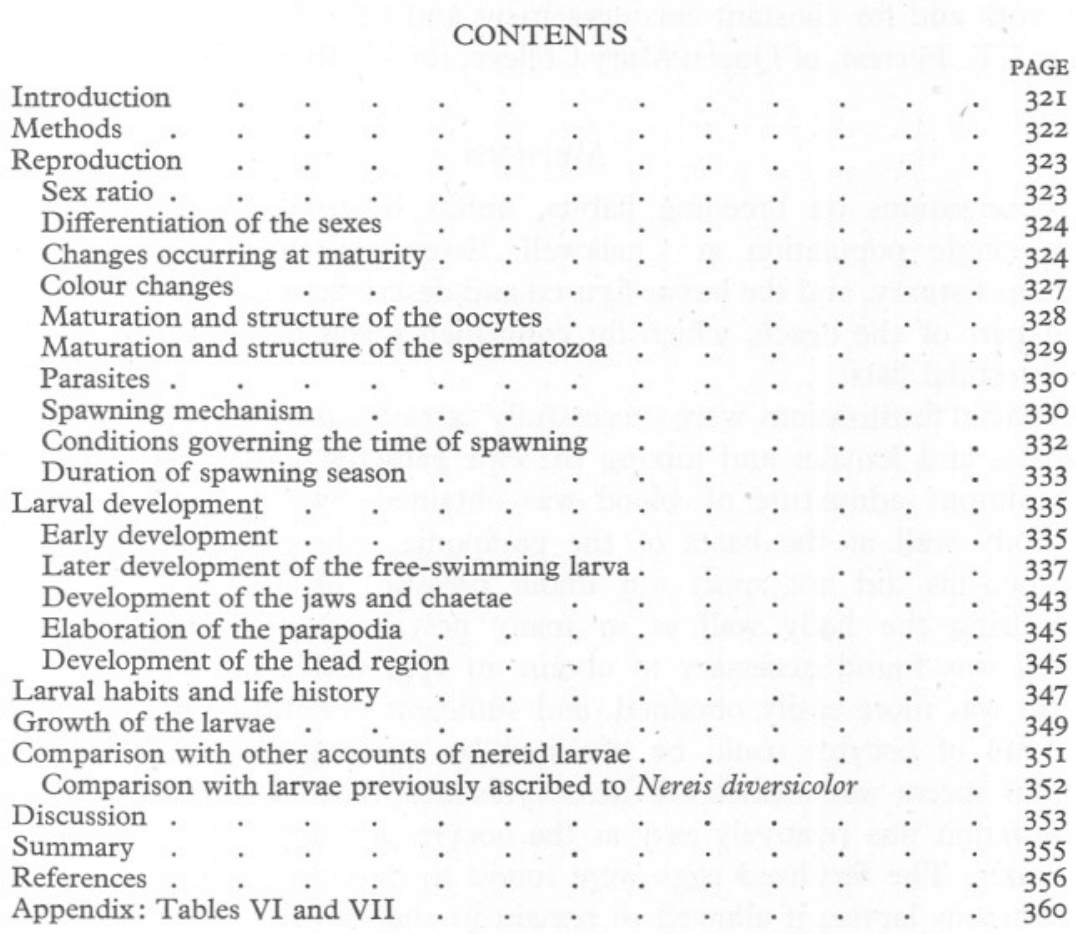

\section{INTRODUCTION}

It is somewhat surprising that although Nereis diversicolor O. F. Müller is one of the commonest of all shore polychaetes in the British Isles and northwestern Europe, its early development has hitherto been unknown. The species has, however, attracted considerable attention and many divergent views have been expressed about its reproductive habits.

The present paper presents a reasonably complete account of the larval life history, and also a discussion of the diverse views expressed about various aspects of its reproductive habits. 
The most interesting points discussed, apart from the development of the larvae in the mud, are the existence of a form of pseudo-copulation, the absence of an epitoquous stage, and the general absence of the phenomena of hermaphroditism (Mendthal, I889), parthenogenesis (Schultze, I856; Herpin, I923 $a$, I925, etc.), and viviparity (Schröder, I886; Gravier, I905; Benham, I9I0; MacGinitie \& MacGinitie, I949) previously attributed to the species by these authors.

I am glad to have this opportunity of expressing my thanks to Dr G. E. Newell, of Queen Mary College, for the original suggestion of the subject of this work and for constant encouragement and help during its progress, and to Dr J. E. Forrest, of Queen Mary College, for kindly reading the typescript.

\section{METHODS}

All observations on breeding habits, unless otherwise stated, were made on a single population at Chalkwell, Essex, on the north side of the Thames Estuary, and the larvae figured and described were collected from the same part of the beach, which for convenience was near the upper limit of the intertidal flats.

Artificial fertilizations were successfully carried out by opening the coeloms of males and females and mixing the ripe gametes in shallow glass dishes. A minimum admixture of blood was obtained by slitting or puncturing the body wall at the bases of the parapodia, where it is relatively thin. The oocytes did not spurt out under pressure of the coelomic fluid on puncturing the body wall as in many polychaetes, and fairly extensive slitting was found necessary to obtain an appreciable quantity of oocytes. Sperm was more easily obtained, and sufficient quantity to fertilize a Petri dish full of oocytes could be obtained by pricking a single parapodium. Surplus sperm was washed off the oocytes after fertilization had taken place. Decantation was relatively easy as the oocytes are appreciably heavier than sea water. The fertilized eggs were found to develop well, as far as young chaetigerous larvae, if allowed to remain in shallow dishes in which the sea water was changed daily, no further attention being required.

Larvae were obtained from the mud by digging trenches through areas in which the worms were most numerous, stirring the sea water which percolated into the trench, well rinsing the overturned mud containing the adults back into the trench, and then passing this water through a fine silk net. This method which has been used to collect larvae of other polychaetes, is described by Newell (1949), and is fairly efficient when the larvae are numerous. On return to the laboratory, the water containing the larvae was poured out into Petri dishes and the silt allowed to sediment out. The larvae were then searched for under a binocular microscope, and picked out with a fine pipette. 
Drawings were made with a camera lucida, those of larvae having been made from typical living specimens temporarily narcotized with a drop of $8 \%$ magnesium sulphate and examined without a cover-glass. When larvae are left in this fluid for some time, the cilia continue to beat for about ro min. after the larvae have ceased other movements, so that the ciliary tracts may be made out fairly well. If not allowed to remain too long in the narcotic, larvae were found to revive completely when replaced in fresh sea water.

Permanent mounts of larvae either unstained or stained with borax or alum carmine in euparal or balsam revealed no more anatomical detail than in the living state. However, details of such structures as the jaws and chaetae could be seen more easily in benzyl alcohol. This medium was found most satisfactory for examination of fixed, unstained larvae, providing these were not left too long in the fluid before examination.

The larvae fixed well in $5 \%$ formalin in sea water, after being narcotized in $8 \%$ magnesium sulphate. They were allowed to remain in the formalin for about 2 days, and were then transferred and stored in $30 \%$ alcohol.

Sections of adults were cut at 8 and ro $\mu$, after fixation in cold Bouin's fluid, and stained with Ehrlich's haematoxylin with eosin as a counterstain.

The beach temperatures shown in Text-fig. I I were recorded by a combined maximum-minimum thermometer lying at a depth of about $10 \mathrm{~cm}$. in the mud, and protected by a heavy brass cylinder loosely plugged with cotton-wool at each end.

\section{REPRODUCTION}

Sex Ratio

McIntosh (1907), at St Andrews, found that the great majority of individuals examined in December were females; and Dehorne (I925) also notes that the number of females is greatly in excess of the males. Schröder (I886) found three males in a sample of forty-eight $(6 \cdot 25 \%)$, and Herpin (I925) found the ratio of males to females at Cherbourg to be $\mathrm{I}: 7$ (about $14.3 \%$ ). Durchon (private communication), on the other hand, reports the males to form as much as $30 \%$ of the population at Luc-sur-Mer. It is this scarcity of males which has been partly responsible for the suggestion that the worm reproduces parthenogenetically. It would appear from these references and from numerous observations made by the writer that this predominance of females is probably universal.

The proportion of males to females naturally varied in any one sample taken during early spring, and this was probably due to the samples being too small, since owing to the relative scarcity of the males comparatively large samples have to be taken to obtain a significant result. It is also possible that the proportion of males to females is different in different localities. At 
Chalkwell, in various samples taken before spawning had taken place the percentage of males varied between $I$ and IO ( 3 in 35,5 in 153,3 in 218 , 4 in 109,9 in 138$)$.

\section{Differentiation of the Sexes}

In the autumn the sexes are externally indistinguishable, although by October the coeloms of the females contain small oocytes and the sexes may be determined by slitting open the body cavity. The oocytes at this stage are rather small $(\operatorname{I00} \mu)$ and cannot be seen without the aid of a good lens.

In summer and autumn all the worms assume a reddish brown colour, but in early spring become bright green. The mature males have a bright grassgreen colour and may thereby be distinguished from the females, which have a much darker green colour which is often lacking on the ventral side at this stage. The ripe males, that is, males containing free sperm, are completely green, and the red and brown pigments, which are usually still recognizable in the ripe female, cannot be seen in the male. The white mass of sperm which by then packs the coelom of the male gives the sex its lighter green colour, and when the sperm has been shed the males are appreciably darker in colour.

Apart from colour differences, the mature female may be recognized on the shore by slightly stretching the animal between the fingers when the oocytes, which by then are quite large $(200 \mu)$ and visible to the naked eye, may under favourable conditions be seen moving with the coelomic fluid.

In many nereids the males when mature may be distinguished by the development of an anal rosette, the sperm being discharged through the anus after histolysis of the gut (Gravier, I923a). This does not appear to be so in $N$. diversicolor, and no anal rosette could be distinguished in mature or spawned males.

\section{Changes Occurring at Maturity}

Most recent authorities agree that $N$. diversicolor is typically atoquous. Changes, or instances of partial metamorphosis (i.e. change of body form as a preliminary to spawning usually resulting in a free-swimming epitoquous or 'heteronereid' phase) which have been described may be regarded as atypical or exceptional; while the occurrence of completely epitoquous forms ascribed to this species is probably due to a confusion of species. These problems are considered in more detail in the discussion.

Although the process of metamorphosis of normal individuals into an epitoquous form is normally lacking in $N$. diversicolor, some well-marked changes do, however, occur. Thus, early in the development of the female germ cells, the coelom becomes filled with a large number of coelomic corpuscles which eventually come to form a very loose parenchyma or pseudotissue. Claparède (1868) was one of the first to comment on this phenomenon which since then has received attention from several workers, especially Romieu (I92 I $a, b$ ), Dehorne (I922 $a, b$, I924, I925), Herpin (I92I, I925) and 
Thomas (I930 b). McIntosh (I907, I9I0) also refers to the formation of this loose 'ovigerous tissue' as being possibly derived from the dorsal organ of Goodrich, and becoming attached to the vessels and the bases of the parapodia. He also notes an increase in the vascularity of the gut in December and that, when the oocytes become free in the coelom, masses of coarsely granular cells appeared sometimes in lobular masses in the region of the dorsal ciliated organ. He considered these masses of cells to be correlated with the growth of the oocytes. Herpin (1925) found, in individuals in which the sexual products were in an advanced state of development, that the coelomic corpuscles (éléocytes) contained fusiform bodies which were in fact fragments of muscle fibre. These éléocytes (he remarks) evidently have the same role as in nereids, which metamorphose at the breeding season into 'heteronereids', that is, in becoming actively phagocytic and digesting the muscle which undergoes histolysis towards maturity. This phenomenon has been studied by Romieu and Dehorne primarily in Perinereis cultrifera, but also in Nereis diversicolor. In the four papers mentioned above, Dehorne made a close study of these changes and found that there was no doubt that the spindle-shaped bodies in the phagocytes were in fact muscle fibres. He pointed out $(1922 a, b)$ that this process of phagocytosis is probably not due to a precocious invasion of the tissues by the phagocytes, but that it is more likely a result of the muscle fibres breaking up spontaneously, and their fragments then being taken up by the cells. This process is carried out over a fairly prolonged period, and the phagocytes may be regarded as specialized coelomic corpuscles.

Two phases of activity of the coelomic corpuscles may therefore be distinguished. These phases, pointed out by Dehorne (I924), were identified in the Chalkwell population.

(i) Coelom filled with a heterogeneous mass of cells. (Referred to as 'parenchyma' in the present paper, and equivalent to Claparède's 'tissue connectif', McIntosh's 'ovigerous tissue', Kükenthal's 'lymphoiden Zellen', Heinen's 'Protoplasmaschicht' and Schneider's 'blasigen Gewebes'.) The formation of this loose parenchyma is presumably correlated with the development of the female germ cells, for its cells appear to be largely responsible for the deposition of yolk in the oocytes (Kükenthal, I885; Schröder, I886; McIntosh, I907, I910; Herpin, I925; and also in Perinereis cultrifera; Romieu, I92I $a, b)$. According to Dehorne the nuclei of the oocytes during this early stage are rather irregular in shape, and most of the coelomic corpuscles remain in the region of the dorsal ciliated organ. The muscles remain intact.

(ii) This loose coelomic parenchyma disappears. The mature oocytes come to fill most of the coelom, and histolysis of the muscle layers begins. The nuclei of the oocytes are now spherical and the coelom contains, apart from the oocytes, fragments of muscle fibre and phagocytes.

This gradual digestion of the muscle layers by the phagocytes enables the 
oocytes to be released by the splitting of the body wall, which has become very thin by the time that spawning is ready to take place. In the specimens of Nereis diversicolor from Chalkwell, however, the degree to which histolysis had proceeded at the onset of the spawning period was rather variable, and was not readily detected even in some apparently mature females. Generally, however, the worms were abnormally fragile in early spring some time before spawning, and this was presumably due to the histolysis of the body-wall muscles described above. Sections of some adults showed almost complete histolysis in some instances, but in others reduction in the muscle layers was hardly noticeable. The appearance of the coelom during these various phases is shown in Text-fig. I, and Plate I, figs. I, 3-5. Histolysis of the muscle layers is also referred to by McIntosh (1907, I910).

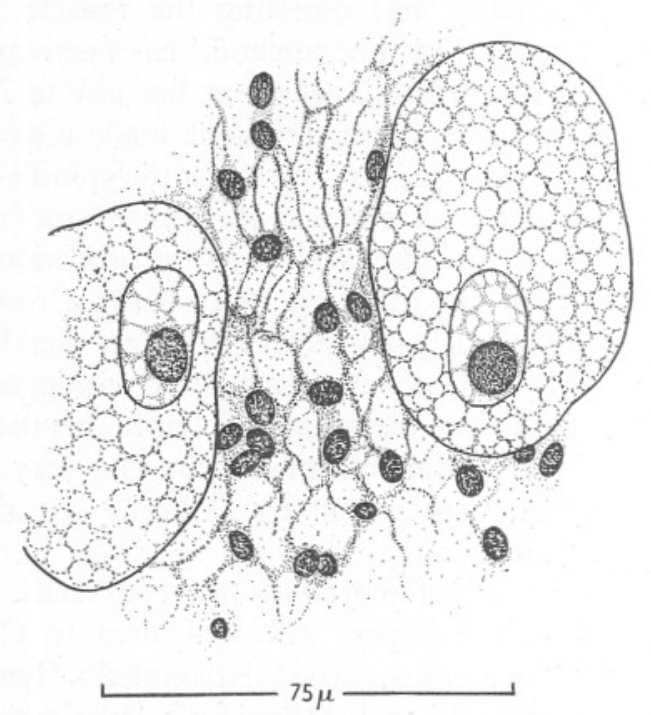

Text-fig. I. Young coelomic oocytes. Young oocytes are seen imbedded in the parenchyma.

Thieren (1909) concluded that this histolysis is caused by unfavourable conditions and insufficient oxygen supply, and that breaking down of the tissues occurs where the oxygen consumption is normally highest; and also that this, in $N$. diversicolor, facilitates spawning before the assumption of an epitoquous stage is completed by the individual. He suggested that histolysis may also be caused by internal secretions, or as a corollary of normal metamorphosis. Thieren's suggestion, however, that spawning takes place before metamorphosis into an epitoquous stage has begun, thus explaining the atoquous habit, cannot be supported since no further change appears to occur in unspawned individuals in which the oocytes eventually break down, and which usually die off before the next winter without showing any signs of 
metamorphosis. Dehorne (I922b), indeed, concludes that as phagocytosis occurs in $N$. diversicolor which is atoquous, the process may be regarded as independent of metamorphosis.

In the male, the first phase in the activity of the coelomic corpuscles, that is the formation of a loose parenchyma, is of very short duration, and this supports the hypothesis that the formation of the coelomic matrix in the female is concerned mainly with the growth of the oocytes and the deposition of yolk. On the other hand, histolysis occurs in the male as well as in the female, and often appears to be taken much further in the male. The relation of this to spawning is discussed below.

\section{Colour Changes}

The colour change occurring at maturity is one of the most interesting aspects of the reproduction of this species, and has been noted by several previous workers (Mendthal, I889; de St Joseph, I906; McIntosh, I907, I9I0; Herpin, I923a, I925; Dehorne, I925; Thomas I930a).

Mendthal considered this green colour to be due to a diet of green algae. McIntosh, however, who also found green females in January, rejected this explanation and concluded that this colour was due to the presence of 'pale greenish ova', yet he states that the sexes are not always distinguished by colour differences and reports finding both males and females of a greenish or dull yellowish colour, of which the males were usually paler. McIntosh offers no explanation of the cause of the coloration in the male sex; but his general observations on the slight colour differences between the sexes are in accordance with the observations made at Chalkwell.

The coloration of $N$. diversicolor is being investigated, and as it is hoped to publish the results separately, only a brief outline of the process of colour change is given here. In either sex the assumption of the green coloration occurs about the same time as the onset of histolysis, the phagocytes in the coelom being richly charged with granules of a bright green pigment which later becomes deposited under the cuticle. This general green colour is apparently correlated with maturity, and at Chalkwell the percentage of green worms rose steadily to practically $100 \%$ just after the main spawning period, afterwards dropping steadily during early summer. In December, for example, only a very few green worms were found; in late February and March, on the other hand, practically all the worms were green; while by the end of May only very occasional specimens bore traces of green pigment. Such individuals were invariably found to contain mature oocytes in contrast with those with a reddish brown colour, which were either empty or contained a milky fluid formed from broken-down oocytes. This correlation was found to be statistically significant. The females appear to lag behind the males slightly in assuming the green colour. No support was found for the explanations of the presence of green pigment made by Mendthal or McIntosh. 
It is also interesting to note here that $N$. japonica which appears to be closely related to $N$. diversicolor, and with which it was originally confused, also becomes green at maturity (Izuka, 1908), although, unlike $N$. diversicolor, $N$. japonica possesses an epitoquous phase.

\section{Maturation and Structure of the Oocytes}

Schröder (I886), Mendthal (I889), Schneider (I902), and Heinen (I9II) agree that the female sex cells arise in the ventral region of the body in relation to the ventral vessel and between the bases of the parapodia, and it was confirmed that the germinal epithelium appears to proliferate in the ventral part of the coelom in the septal region in the worms collected at Chalkwell. The cells which eventually divide to form the female germ cells, however, break loose into the coelom at a very early stage.

\section{Table I. Measurement of Oocytes}

\begin{tabular}{|c|c|c|c|c|c|c|c|}
\hline Size $(\mu)$ & Sept. 1949 & Oct. 1948 & Nov. 1948 & Dec. 1948 & Jan. 1949 & Feb. 1949 & Mar. 1949 \\
\hline $0-25$ & - & - & - & - & - & - & - \\
\hline $25-50$ & - & - & - & - & - & - & \\
\hline $50-75$ & 3 & 4 & - & - & - & - & 8 \\
\hline $\begin{array}{r}75-100 \\
100-125\end{array}$ & 6 & 5 & - & 一 & - & - & I \\
\hline $100-125$ & 28 & 32 & - & - & - & - & \\
\hline I25-I 50 & 13 & I9 & 一 & - & - & - & - \\
\hline $150-175$ & 8 & 56 & 32 & 8 & - & - & - \\
\hline $175-200$ & - & 7 & 46 & $4 \mathrm{I}$ & 4 & 5 & 4 \\
\hline $200-225$ & - & I & $2 \mathrm{I}$ & 46 & 38 & I4 & II \\
\hline $225-250$ & - & - & 5 & 7 & 80 & 59 & $5 \mathrm{I}$ \\
\hline $250-275$ & - & - & - & - & I9 & 24 & I7 \\
\hline $275-300$ & - & - & - & - & I & I7 & 9 \\
\hline
\end{tabular}

McIntosh (1907, 1910) noted that the size of the oocytes was somewhat variable, but these oocytes from St Andrews were much smaller than those collected from Chalkwell. McIntosh gives the diameter of a mature oocyte as $152.4 \mu$. Herpin (1925) found the maximum oocyte size to lie between 200 and $250 \mu$, and emphasizes that the size variation is much more variable in $N$. diversicolor than in other nereids, noting that the mature oocytes may have a diameter of less than $200 \mu$. This is confirmed by Durchon (private communication), who found the diameter to vary between 190 and $240 \mu$. The size of the mature oocytes at Chalkwell varied between about 200 and $275 \mu$ in diameter, the mean oocyte size at the time of spawning being about $220 \mu$. The actual range in size of coelomic oocytes is shown in Table I.

The coelomic germ cells in the female are first recognizable in young worms about $7 \mathrm{~cm}$. in length, when they are at least 6 months old. Dehorne (1925), it is true, found oocytes free in the coelom of worms only $5 \mathrm{~cm}$. in length, but it is likely that these would actually appear longer if measured after narcotization with Io \% magnesium sulphate as here employed.

Apart from the first few segments in the pharyngeal region and the most posterior segments, oocytes may be found throughout the length of the body. 
At Chalkwell, samples of worms were taken throughout the year and about twenty specimens randomly selected. A few oocytes were taken from each, and about Ioo measured. The range in size is shown in Table I. The mean oocyte size was calculated and was found to increase steadily over the winter months, reaching a constant maximum size rather before the main spawning period. This provides a useful method of prediction of spawning time, as pointed out by Newell (1948, 1949). Oocytes were found in the coelom from early September to early May, but were absent during the summer months.

When mature, the oocytes come to fill the main body cavity and the spaces in the parapodia, frequently becoming crushed together. On slitting open the coelom of a mature female the oocytes which are released are often dented and rather irregular in outline through being crammed together, but when not dented are practically spherical. On contact with sea water they quickly round off. They are a very pale straw colour, and not pale green as noted by McIntosh (1907). A large central germinal vesicle is surrounded by a highly granular cytoplasmic area composed of rounded yolk globules (Text-fig. I).

The larger oily droplets observed in some other species of Nereis (E. B. Wilson, I892; Herpin, I925; D. P. Wilson, I932, etc.) are not visible in $N$. diversicolor. This may be correlated with the typical bottom development of the larvae of this species, since these droplets appear to occur in typically pelagic nereid larvae.

After the spawning period has passed, the oocytes in the females which have not spawned gradually break down into a white milky mass in the coelom, the observations made by the writer being in accordance with those made by McIntosh (I907). Oocytes remain in the coelom for nearly 2 months after the main spawning period before finally breaking down. Thomas (I930 $b$ ) found that the oocytes were invaded by a chromolipoid pigment, the cytoplasmic constituents disappearing, the corpuscles becoming actively phagocytic, and surrounding the degenerating oocytes during this process.

\section{Maturation and Structure of the Spermatozoa}

In the male the loose parenchyma is transitory, and the sperm mother cells, which presumably originate from the coelomic epithelium in much the same position as the oocytes, break away into the coelom in small groups. These 'sperm plates' as they may be called, are very characteristic flattened groups of cells found in many polychaetes, though differing much in size and appearance in different species. In $N$. diversicolor at Chalkwell they were found in the coelom from December until February. The number of cells in each plate or disk increases with age, but free spermatozoa are not formed until the normal breeding season is reached. The young sperms acquire their tails while still attached to form a sperm plate, but soon after they break away 
into the coelom. Males containing mature sperm were found for some 2 weeks before spawning apparently took place.

The ripe spermatozoan (Text-fig. 4) bears a sharply defined acrosome anteriorly, and a tail about $40 \mu$ in length posteriorly.

\section{Parasites}

In a very large proportion of the males found at Chalkwell the coelom was found to contain quantities of a single form of unidentified ciliate which apparently fed on the spermatozoa. The amount of sperm left by the time the spawning period was reached was negligible in some instances, and in these the general body cavity and parapodial spaces were crammed with ciliates.

\section{Spawning Mechanism}

Unfortunately, in spite of much observation, spawning was observed neither under natural conditions on the shore, nor in the laboratory.

There are theoretically four ways in which the germ cells may be released from the coelom: (I) through the nephridia; (2) by the coelomic ducts (ciliated organs) acquiring openings to the exterior during the breeding season; (3) through the anus after histolysis and perforation of the gut; (4) by rupture of the body wall.

\section{Release of the Oocytes}

The first of these methods was maintained by Mendthal (I889), though the oocytes are manifestly too large for it to occur. Regarding the second method, Benham (I9IO) suggested that the ciliated organs might acquire openings to the exterior, but this may be discounted in light of recent work by Goodrich (1945). Goodrich, however, was obviously not convinced or did not realize that $N$. diversicolor is atoquous, since he suggested that atoquous nereids might have functional ducts. This has not been found to be so. Regarding the third method, it may be assumed that it is extremely unlikely that oocytes would ever be discharged through the anus. Release of the oocytes by rupture of the body wall has been observed by Herpin (1925), who describes the shedding of oocytes as being preceded by contraction of the posterior end of the body. McIntosh (1907) also expresses the opinion that they are shed by this means, and this is confirmed by Durchon (private communication).

\section{Emission of the Spermatozoa}

As in the female there is no evidence that the ciliated organs acquire openings to the exterior, nor is there any evidence that the sperm is discharged through the anus, since spawned males appeared to have the gut intact, showed no sperm in the gut, and lacked the anal rosette which is developed in Perinereis 
marionii (Herpin, I923a; Gravier, I923b), P. cultrifera (Herpin, I923 $b$; Gravier, I923 $a$; Gravier \& Dantan, I928) and other species.

As a few spawned males which showed no signs of damage to the body wall were found in late February, the sperm is almost certainly discharged through the nephridia, though in some instances emission may accidentally occur by rupture of the body wall.

\section{General considerations}

In the laboratory, apparently, fully mature females could not be induced to spawn in the presence of males, whether placed in glass dishes or in the aquarium in fresh sea water under various conditions of light and temperature; nor in the presence of motile sperm from ripe males. Conversely, ripe males could not be induced to emit sperm when placed together with ripe females, ripe oocytes, or in 'egg-water' from crushed ripe oocytes. Other workers seem to have been rather more successful in this respect with this somewhat temperamental species. Herpin (1925) watched ripe females spawning under laboratory conditions. Just (I940) also found at Roscoff that mature individuals released their gametes into dishes in the laboratory during January and February, and this writer was apparently successful in making artificial fertilizations with these naturally spawned gametes, and in rearing the larvae for 3 months afterwards. Unfortunately, no details are given of the subsequent development, nor is it stated whether the males and females spawned in separate dishes or together, or how this spawning actually took place.

Under natural conditions Dehorne (1925) described a kind of copulation or sexual congress, in which several females were found coiled round a single male. Müller (I77I, see Dehorne, I925) had also apparently seen tangled masses of worms under stones and compared them with tangled masses of macaroni. Dehorne regards this observation of Müller's to have been similar. Herpin (1925) also found males and females coiled or knotted together posteriorly and more or less agglutinated with mucus on the surface of the mud, a condition known locally as 'Roi de rats'. This knotting together is not, of course, specifically related to reproduction, and may be observed in the laboratory whenever too many individuals are confined together in a tank, and Durchon (private communication) also concludes that this is probably a purely accidental phenomenon. Herpin supports Dehorne's conclusion that a form of sexual congress occurs in which clusters of females come to surround a single male. Herpin concludes that the ripe females swim in search of the males during the night, and that a tangle of females forms round each male, the oocytes being gradually released and fertilized by the sperm emitted by the male.

Dehorne (1925) also mentions that the females are positively attracted by the secretions of the male, and that when in contact provoke the emission of sperm. He points out that usually, as in epitoquous nereids, it is the males 
which stimulate the females to release their oocytes, but here, owing to the rarity of the males, the reverse seems to occur. Thorson (1946) states that it may be regarded as a general ecological rule that it is the males which stimulate the females; but he notes that there are exceptions. Galtsoff (I940), for example, found in Gryphaea virginica that though chemical stimulation was specific for females, this was not so for males. Townsend (1939), confirming the 'fertilizin' theory of Lillie, and Just $(\mathrm{I} 930 a, b)$ found that the reaction of the male of Nereis limbata was extremely specific to glutathione which is present in the unfertilized oocyte, and this appears to be fairly general, though no experiments appear to have been performed on $N$. diversicolor. Although Dehorne concludes that this species is an exception to the general rule in relation to the comparative rarity of the males, it does not necessarily follow from this fact that it is the females which seek out the males and prompt spawning. It may well be that having come in contact with a male by chance or by attraction by some other stimulus, it is the male which actually initiates the simultaneous emission of the gametes.

\section{Conditions Governing the Time of Spawning}

At Chalkwell, spawning took place in 1949 within 2 weeks centred around the third lunar quarter in late February. At this time both males and females had apparently been mature for about 2 weeks. At the time of spawning a sharp rise in temperature occurred. Authorities seem to differ as to the actual time of year when spawning takes place, but this is discussed later.

The fact that the spawning period centred round the third lunar quarter is interesting in that it is at this phase that many epitoquous nereids spawn. Whether this is in fact a lunar effect, in N. diversicolor, is not known, and can only be determined after study for a number of years. This problem has been given much attention by Fox (1932) and by Amirthalingham (1928), who concluded that apparent correlation with lunar phase was due to several practicably inseparable effects. It is worth noting, however, that Newell (1948) found a correlation with a lunar phase at which spawning took place over a sharply defined period, in the common lugworm Arenicola marina, whose habitat is not widely different from that of the species under consideration.

Although factors relating to the lunar effect may possibly be correlated with the growth of the gametes, the actual stimulus required to initiate spawning is frequently the attainment of a definite threshold temperature or temperature change (Orton, 1920; Thorson, 1946). At Chalkwell, as already mentioned, spawning took place at a time when there was a marked rise in temperature, and may have been stimulated in this way. The temperature during the week when the main spawning took place varied between 5 and $8.8^{\circ} \mathrm{C}$.

From a study of size distributions of adult populations obtained from various stations on British coasts, it may be concluded that spawning generally takes place in early spring, and the fact that McIntosh found spawning to take 
place in east Scotland about a month later than the writer found in southern England again suggests that a threshold temperature may be the factor initiating spawning.

\section{Duration of Spawning Season}

The variability of the reproductive habits within a single species of nereid is notorious, and this, together with the possibility of confusion of the species of Nereis to which the various larvae have been ascribed, makes it difficult to assess the value to be attached to reports of $N$. diversicolor larvae occurring at widely different seasons of the year. Information from various sources which throw light on these points is summarized in Table II.

\section{TABle II. BReEding Period of NEREIS DIVERSICOLOR}

\begin{tabular}{|c|c|c|c|c|c|c|c|c|c|c|c|c|c|}
\hline $\begin{array}{l}\text { Author } \\
\text { Present } \\
\text { paper }\end{array}$ & $\begin{array}{c}\text { Locality } \\
\text { Chalkwell, } \\
\text { England }\end{array}$ & $\begin{array}{c}\text { Jan. } \\
\mathrm{O}\end{array}$ & $\begin{array}{l}\text { Feb. } \\
\text { O, S }\end{array}$ & $\begin{array}{l}\text { Mar. } \\
\mathrm{O}, \mathrm{L}\end{array}$ & $\begin{array}{l}\text { Apr. } \\
\text { O, L }\end{array}$ & May & $\begin{array}{l}\text { June } \\
-\end{array}$ & July & $\begin{array}{l}\text { Aug. } \\
-\end{array}$ & $\begin{array}{l}\text { Sept. } \\
\text { O }\end{array}$ & $\begin{array}{l}\text { Oct. } \\
\text { O }\end{array}$ & $\begin{array}{l}\text { Nov. } \\
\text { O }\end{array}$ & $\begin{array}{l}\text { Dec } \\
\text { O }\end{array}$ \\
\hline McIntosh & $\begin{array}{l}\text { St Andrews, } \\
\text { Scotland }\end{array}$ & $\mathrm{o}$ & $\mathrm{O}$ & $\mathrm{O}, \mathrm{s}$ & - & - & - & - & - & - & o & o & o \\
\hline $\begin{array}{l}\text { Thamdrup } \\
\text { Just }\end{array}$ & $\begin{array}{l}\text { Skallingen } \\
\text { Roscoff }\end{array}$ & $\bar{s}$ & $\bar{s}$ & $\underline{\mathrm{o}}$ & o & $\underline{\mathrm{o}}$ & $\underline{\mathrm{O}}$ & $\underline{0}$ & 二 & 二 & 二 & 二 & 二 \\
\hline $\begin{array}{l}\text { Smidt } \\
\text { Herpin }\end{array}$ & Copenhagen & $\frac{3}{5}$ & $\frac{s}{S}$ & $\bar{s}$ & $\mathrm{~L}$ & $\stackrel{\mathrm{L}}{\mathrm{S}}$ & $\mathrm{L}_{\mathrm{S}}$ & L & $\mathrm{L}$ & L & $\mathrm{L}_{\mathrm{S}}$ & $\overline{\mathrm{L}}$ & s \\
\hline Nunn & Plymouth & - & $\underline{-}$ & - & O & $\underline{-}$ & $\underline{-}$ & $\frac{3}{x}$ & $\frac{3}{x}$ & $\underline{-}$ & - & - & - \\
\hline Hofker & Zuidersee & - & 一 & - & - & - & - & $\mathrm{L}$ & $\mathrm{L}$ & - & - & - & - \\
\hline Thorson & Øresund & - & 一 & $\mathrm{L}$ & $\mathrm{L}$ & $\mathrm{L}$ & L & L & L & - & - & - & \\
\hline $\begin{array}{l}\text { Blegvad } \\
\text { Mendthal }\end{array}$ & $\begin{array}{l}\text { Nyborg } \\
\text { B, of Pillau }\end{array}$ & 二 & 二 & 二 & $\underline{0}$ & 二 & $\overline{\mathrm{o}}$ & 二 & $=$ & $=$ & $=$ & $\bar{z}$ & \\
\hline Durchon & Luc-sur-Mer & - & $\mathrm{s}$ & $\mathrm{s}$ & $\mathrm{s}$ & - & - & - & - & - & 二 & 二 & 二 \\
\hline
\end{tabular}

Thorson (1946) points out that the length of the breeding season of any marine organism may depend on three main factors. With reference to $N$. diversicolor these may be summarized as:

(i) Vertical distribution on the shore, with resulting effects, e.g., a graded temperature, so that a possible optimum spawning temperature will be reached progressively later at greater depths.

(ii) Variation in the time taken by populations or individuals to mature.

(iii) Repetition of spawning by the same individuals within one season, or protraction of spawning over a period.

The first factor seems most likely to promote an extended breeding season, Herpin (1925) regards this and the variability of habitat to cause spawning to take place all the year round at Cherbourg. Also, if this occurs together with migrations of individuals between the levels, the breeding season may actually be extended at any one locality.

With regard to the second factor, it may be noted that a small number of individuals of both sexes are sometimes slow in maturing. In late summer one or two mature worms may be found, and these may be successful in spawning. Usually these late maturing females are so few that the chance of coming in contact with a ripe male is remote, but the possibility remains, especially when the number of males is relatively high. 
The third effect is not found in this species. Individuals die soon after spawning, and unspawned worms may last only the summer, for the length of life does not appear to cover more than one breeding season. Also, in any one worm the gametes are all much in the same state of development, which suggests that the spawning period is restricted. McIntosh (1907, I9I0) found females in January and February which he considered to have partially spawned, but these may have been immature worms.

As already noted, spawning at Chalkwell took place between 13 and 27 February, and from that time onwards larvae were obtained from the natural habitat in sufficient numbers to make quantitative counts of the
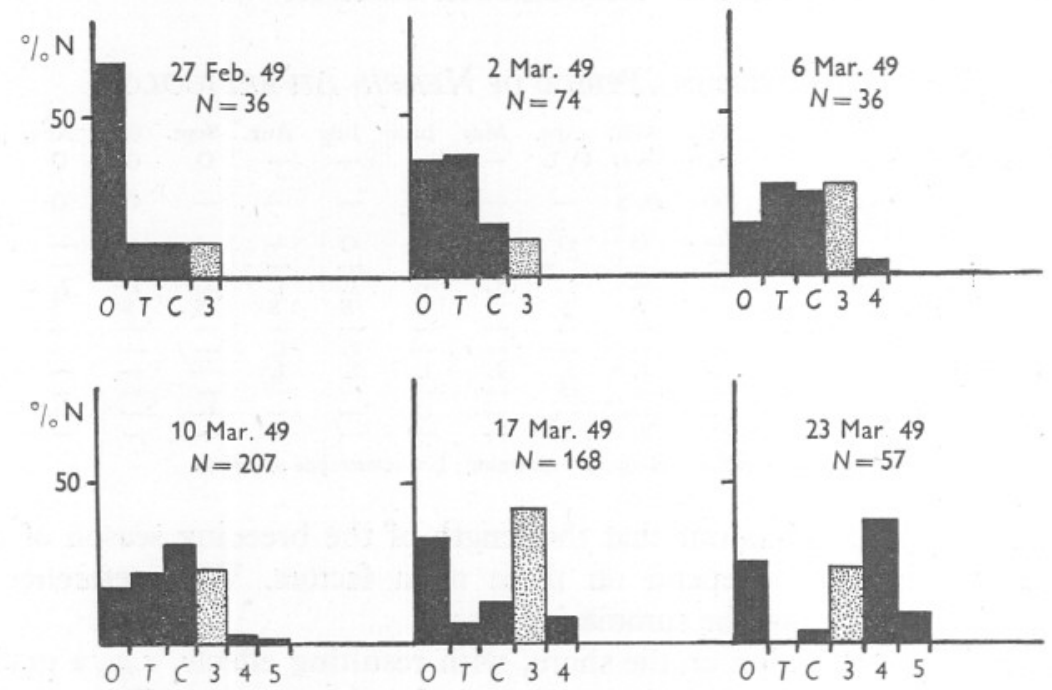

Text-fig. 2. Histograms of relative numbers of larvae at various stages. $O$, unfertilized oocytes; $T$, trochophores; $C$, early chaetigerous larvae; $3,4,5$ larvae with three, four or five chaetigerous segments respectively.

various larval stages possible. The numbers of larvae at different stages are represented as percentages of the total on each date, and shown as a series of histograms in Text-fig. 2. These represent counts of larvae taken at 3-day or weekly intervals, up to a month after the main spawning date. Further samples were taken, but these merely show a steady drift along the abscissa. Larvae were not found later, in summer. The diagrams also show that some oocytes continue to be discharged into the sand after the spawning period, but owing to the absence of males or for some other reason, these were not fertilized. In artificial fertilizations unfertilized oocytes retained their original appearance and showed no signs of degeneration for as much as Io days in fresh sea water, but it seems unlikely that even in the natural habitat oocytes would remain in a healthy state for as long as 5 weeks. Presumably these are released accidentally by unspawned females. 


\section{LARVAL DeVELOPMENT}

\section{Early Development}

Early development seems to follow the general plan already described for other species. Cleavage is spiral and is dextrorotatory, as described by Wilson (I892) for N. limbata and N. megalops. The thick gelatinous envelopes described in these and other species (Herpin, I925) are not always present in $N$. diversicolor.

The early development was followed from artificial fertilizations. Fertilization membranes are thrown off between 0.5 and $2 \mathrm{hr}$. after mixing the gametes (Text-fig. 3). The membrane gradually crumples off the surface of the egg and eventually stands away from its surface at a distance which varied in different fertilizations (Costello \& Young, 1939) and with gametes at different stages of maturity.

A jelly layer was sometimes extruded after fertilization, and was clearly visible by the time the later cleavage stages were reached owing to the adhering sperm and bacteria. These layers were apparently absent as a rule, and were never seen in nature surrounding cleavage stages or young trochophores.

In cleavage, the $D$-cell of the 4-cell stage was not much larger than the other three blastomeres, and in early cleavages obtained from fertilizations in late January and February (1949), the $D$-cell was not very distinct. Cleavages with immature gametes were generally more or less irregular, so that no welldefined cleavage pattern was discernible. However, the pattern approximated more nearly to the spiral type, with recognizable quartettes of micromeres as the spawning period was approached.

Polar bodies were very small, and owing to the yolky nature of the egg were difficult to detect. Cleavage times varied in different fertilizations but were generally slow, as compared with some other species of Nereis. The cleavage stages figured were drawn $20 \mathrm{hr}$. after fertilization but represent different phases of development.

Quartettes of micromeres became cut off and spread over the remaining megameres which could be seen rather indistinctly lying in the centre of a ball of cells forming the gastrula. The number of megameres remaining varied slightly, and although later larvae had usually only 4,5 or 6 were visible in the monotrochophore.

When the larva begins to rotate, cilia are not visible. Cilia are not easily distinguishable until about the fourth day after fertilization. At first the rotary movement appears to be inside the fertilization membrane, but when the cilia begin to grow out near the animal pole, they appear to penetrate the fertilization membrane, which then becomes the larval cuticle. As a rule, rotation begins about 3 days after fertilization, but in some of the earlier artificial fertilizations the larvae began to rotate as early as the I6-cell stage. At first rotation is never continued for periods of more than a few seconds, separated 

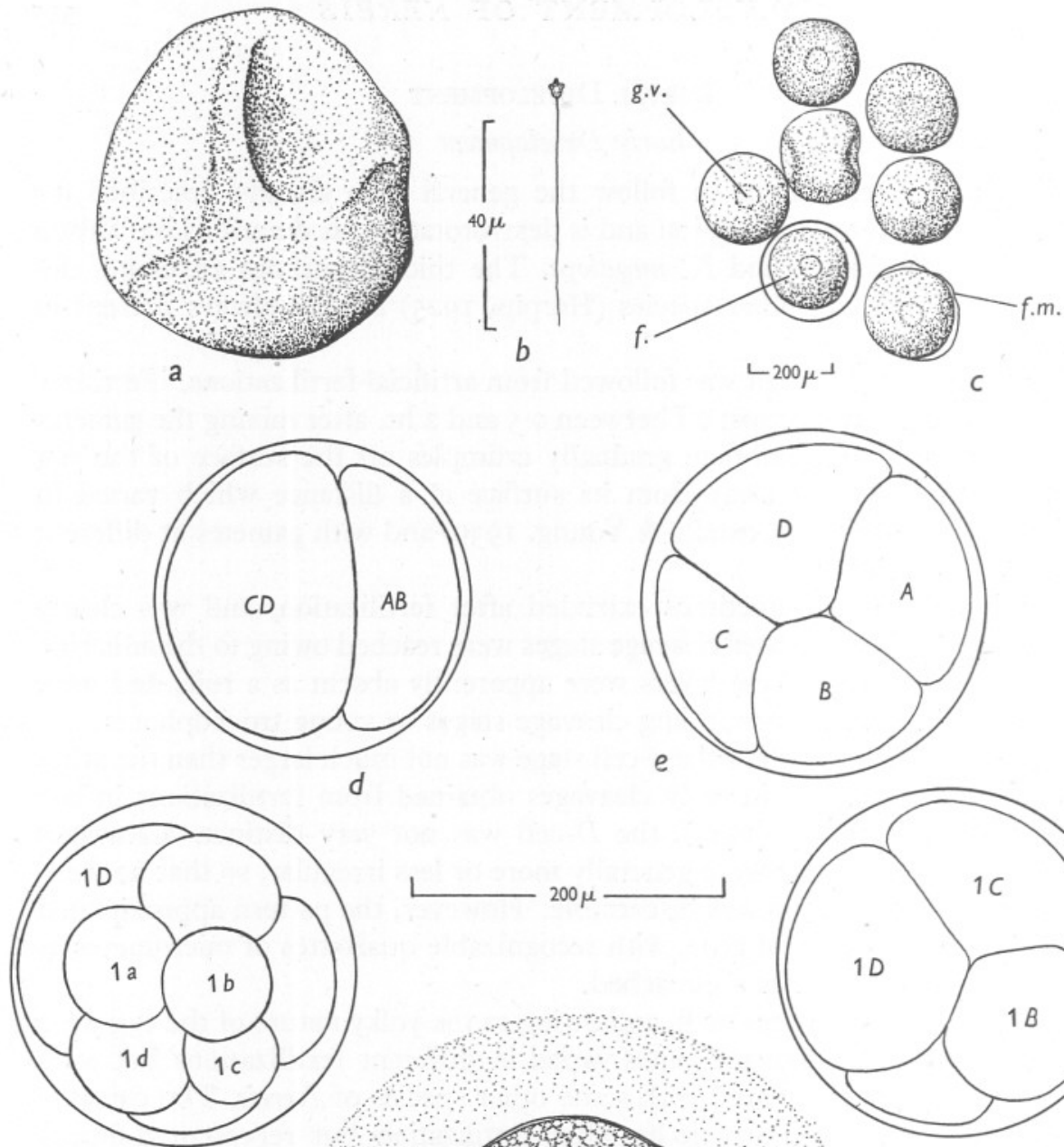

f

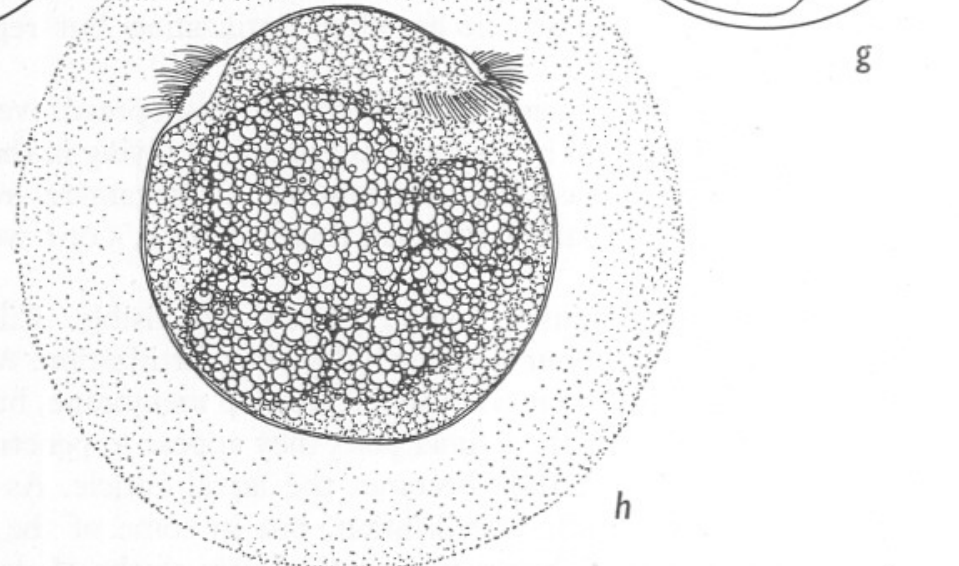

Text-fig. 3. $a$, unfertilized oocyte on release from coelom; $b$, spermatozoan; $c$, spawned eggs ( $f$, fertilized egg, f.m., fertilization membrane, g.v., germinal vesicle); $d$, 2-cell stage; $e, 4$-cell stage; $f$ and $g$, 8-cell stage, seen from animal and vegetable poles; $h$, young monotrochophore with jelly layer. The scale in the centre applies to all except $b$ and $c$. 
by long pauses, but as the larva develops it becomes more vigorous and is continued over progressively longer periods.

At the beginning of the fourth day after fertilization only one large tuft of cilia may be seen in the prototrochal region. This gradually extends round the larva, but is probably never completed (Text-figs. $3 h, 4 a$ ). If a jelly layer is present, the larva, which may now be described as a monotrochophore, breaks through the layer at this stage; but more usually such a 'hatching' process is absent and the gradual extension of the prototroch eventually enables the larva to swim off the bottom instead of merely rotating in one position. The degree of development of the prototroch was found to vary in different larvae.

\section{Later Development of the Free-Swimming Larva}

By the time that the monotrochal stage has been reached the larva has become free-swimming, although its swimming powers are rather limited. Soon after this it begins to elongate slightly, becoming more conical in shape and in side view a faint telotroch may be seen (Text-fig. $4 b$ ). This consists of very fine short cilia and probably contributes little to the locomotory powers of the larva. In many larvae it is difficult to detect, and cannot be seen without narcotization, the prototroch remaining the most important ciliary tract throughout the early larval life. When the telotroch is well developed, however, the swimming is probably better controlled, and whereas previously the monotrochophore was capable only of swimming in circles, by the time that this later stage is reached the larva can, while revolving on its own axis as before, now progress more or less in a straight line. Between four and six megameres can still be seen at this stage, and no chaetae are yet distinguishable.

Very soon after the telotroch is formed, however, chaeta rudiments become visible. Three chaetal sacs are formed simultaneously, each containing four or more rudimentary chaetae, which even at this stage are clearly compound although the distal part is very short, though this quickly elongates when the chaetae project beyond the cuticle (Text-figs. $4 c, d$ ). By the time the first three pairs of bundles of chaetae, which correspond with the first three chaetigerous segments, have come to project beyond the cuticle, the larva is about Io days old. (Age of larvae throughout this paper is reckoned from the time of fertilization.) Very often at this stage four megameres may still be seen quite clearly, but a cavity, the larval gut, gradually comes to surround them (Text-fig. $4 d$ ). The chaetae are still incapable of independent movement, and the larva swims mainly by action of the prototroch. About the same time a slight invagination of the cuticle at the posterior end indicates the formation of the proctodaeum; and at the anterior end a clearer area of protoplasm devoid of any yolk granules may be seen in some larvae. This last feature is of doubtful significance, since it was only clearly recognizable in a few instances. By now the larvae have grown to about $280 \mu$ in length. 

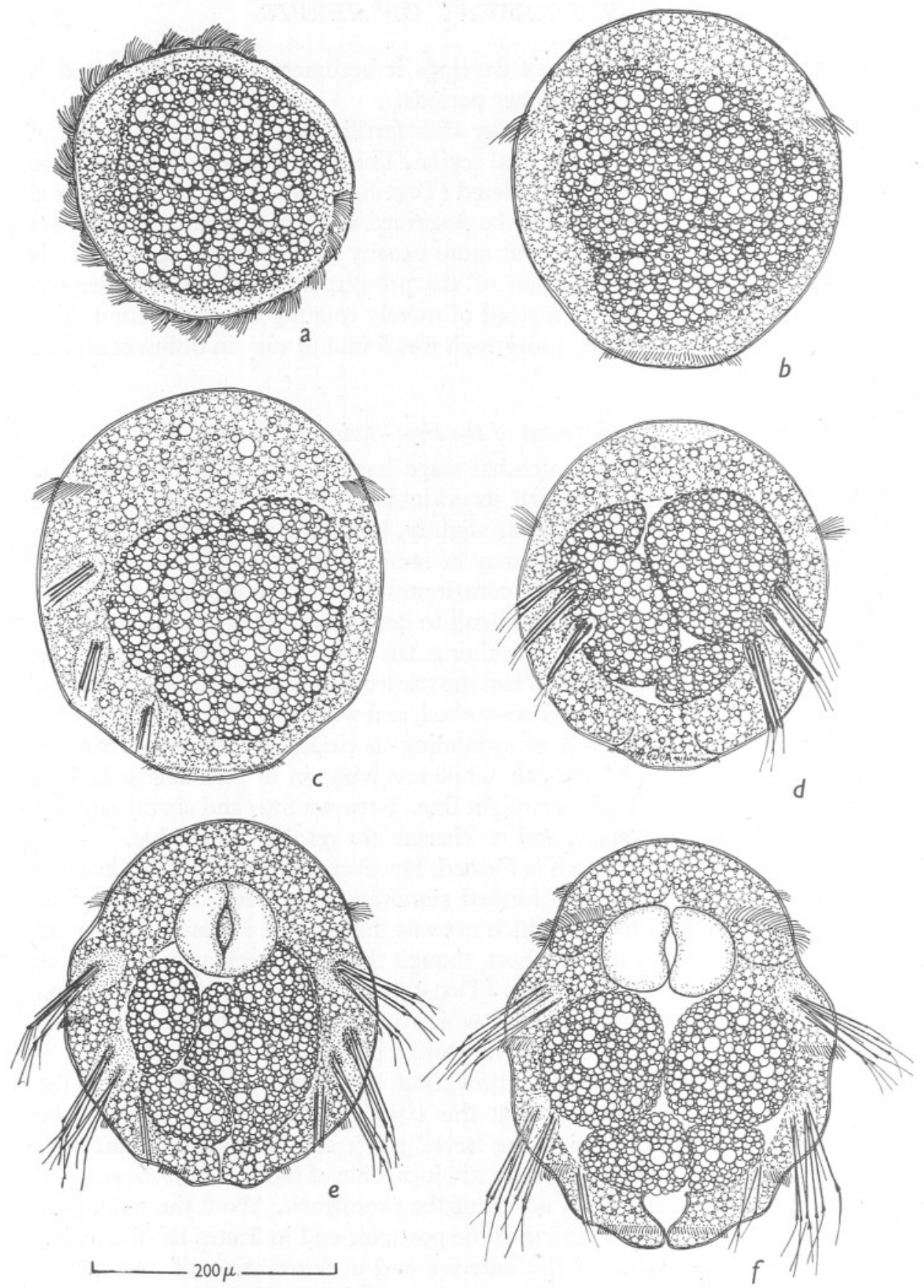

Text-fig. 4. Early stages of the larva: $a$, 'hatching stage' (viewed from animal pole); $b$, slightly later stage showing telotroch (side view); $c$, larva showing early formation of first three chaetal sacs (side view); $d$, early larva with three chaetigerous segments (dorsal view); $e$, larva with three chaetigerous segments (ventral view); $f$, slightly older larva with three chaetigerous segments (ventral view). 


\section{The young chaetigerous larva}

When about 2 weeks old the larvae have reached a length of about $330 \mu$, and may be conveniently termed 'young chaetigerous larvae' to distinguish them from slightly later larvae, which though still possessing only three chaetigerous segments, differ considerably in their external morphology, for they undergo great morphological changes before a fourth segment is added. It is thus convenient to distinguish between 'young chaetigerous larvae' and later 'larvae with three chaetigerous segments', although both stages possess three pairs of chaetal sacs. Although in the young chaetigerous larva the prototroch and telotroch remain in much the same state of development as in the earlier stages, the chaetal sacs soon acquire muscles, and the chaetae become capable of being moved. At first the chaetae in each bundle appear to arise from a single chaetal sac, but neuropodial and notopodial sacs soon become recognizable. The larval gut becomes much more highly developed, the pharynx becoming visible in ventral view as a large spherical mass of clear cells enclosing a median longitudinal cavity. The rectal region and anus can now also be seen, the four remaining macromeres still occupying most of the gut cavity.

The state of development of the different pairs of chaetae bundles is somewhat variable. Frequently all three pairs are equally developed, but in some (Text-fig. 4e) the third pair lag behind the anterior groups in development.

By the end of this stage a slight demarcation of the head region usually makes its appearance. Small patches of cilia may also be seen developing posteriorly to each group of chaetae, and these cilia become quite prominent in some larvae. They are usually composed of longer cilia than those of the telotroch, but are still small enough to be difficult to detect in some larvae, the prototroch remaining the only really prominent ciliary tract. Occasionally a few short cilia-like processes were detected in the apical region, similar to those figured by Wilson (1932) in Nereis pelagica larvae.

\section{The Later Larva with Three Chaetigerous Segments}

There is a considerable amount of differentiation during this stage (Textfigs. $4 f, 5 a, b)$. The rectal and pharyngeal regions of the gut become better developed and simple jaws become visible. Two pairs of simple red eye-cups appear on either side of the head region, and two pairs of short tentacle-like processes grow out from the head. The anterior pair are short and eventually form the prostomial tentacles, while the other pair, which are rather longer, form the first pair of prostomial cirri. Palps are not visible at this stage. The chaetae become more prominent and come to be borne on recognizable, though rudimentary, parapodia (Text-fig. $5^{b}$ ). Anal cirri may also be seen growing out on either side of the anus. They bear fine hair-like processes, similar to those on the prostomial tentacles and peristomial cirri, and are 


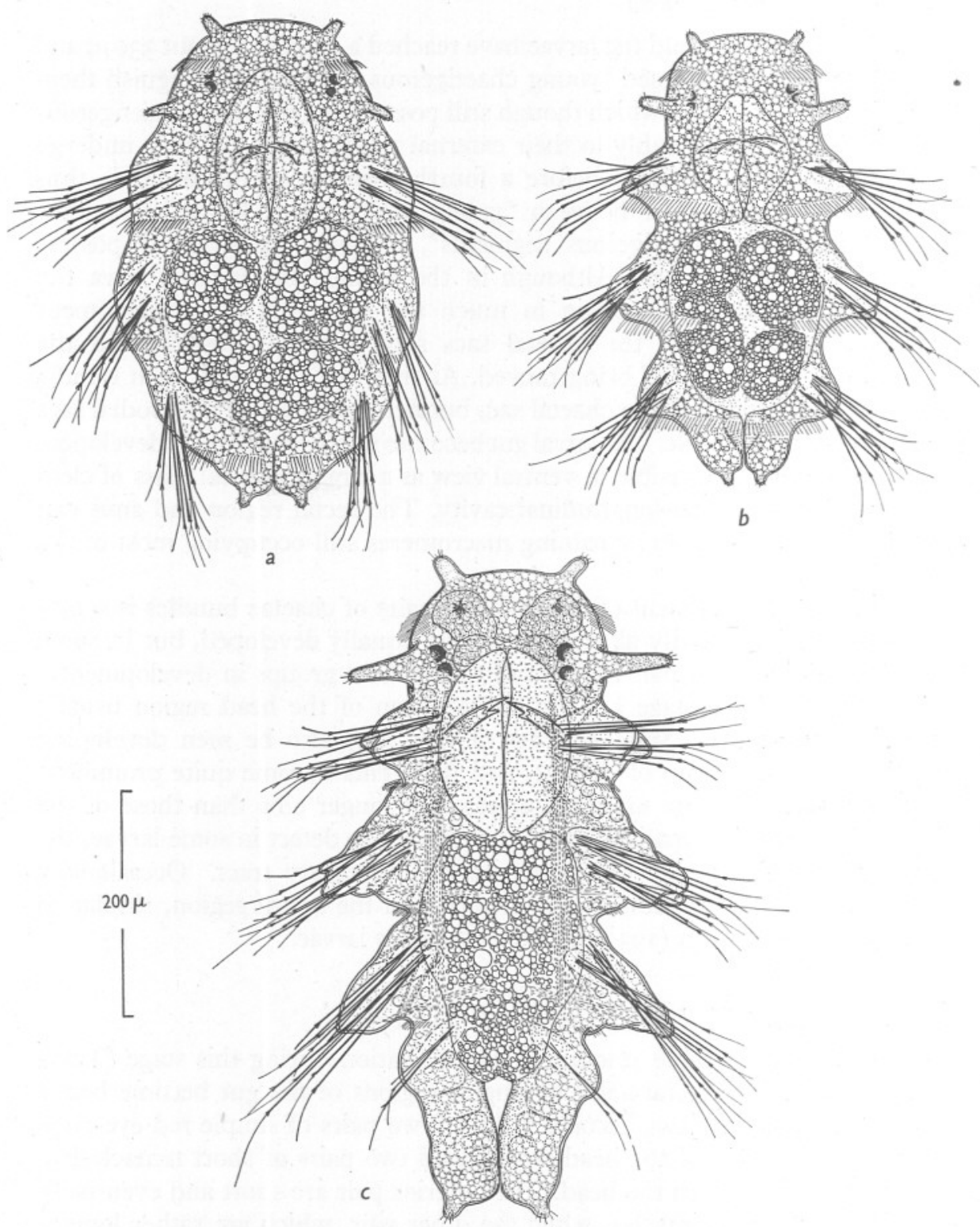

Text-fig. 5. $a$, larva with three chaetigerous segments (dorsal view); $b$, larva with three chaetigerous segments, about 3 weeks old (dorsal view); $c$, larva with four chaetigerous segments, about 4 weeks old (dorsal view). 
presumably sensory structures, which are also characteristic of the adult. By now the larva is about $400 \mu$ long, and is quite active, the chaetae, which are now provided with muscles attached to the bases of the chaetal sacs, being moved fairly vigorously during swimming or crawling.

\section{The Larva with Four Chaetigerous Segments}

By the time that a fourth chaetigerous segment is becoming differentiated the larva is about 4 weeks old and is about $570 \mu$ in length (Text-fig. $5 \mathrm{c}$ ). The ciliated bands remain in much the same condition as in larvae with three chaetigerous segments, but the parapodia are becoming more complex in structure and their musculature greatly increased. The general musculature of the body wall now becomes more prominent; septal muscles are visible in the mid-gut region, and longitudinal muscles may be seen lying on either side of the gut in the dorsal region.

The fourth chaetigerous segment is represented at first by slight outpushings of the body wall, with two or three chaetae in an apparently simple sac. As in all segments during their early phases of growth, definite neuro- and notopodial sacs are not recognizable, and apparently only separate later.

In the head region the palps are becoming more prominent, and small light pigment patches sometimes occur on the dorsal surface of the prostomium just anterior to the two pairs of eye-cups. These presumably correspond to the similar patches described by Wilson (1932) in the larvae of $N$. pelagica, where they may be quite prominent. In $N$. diversicolor larvae, however, they are never obvious and may easily be overlooked in a swimming larva, and are frequently absent. These patches are figured in the larva with four chaetigerous segments shown in Text-fig. 5c. They disappear later, and were never seen in larvae with five or more chaetigerous segments. The jaws become further elaborated and possess another tooth by this stage.

The megameres in the gut have by this time broken down into an amorphous mass of yolk, which still, however, fills the mid-gut region.

\section{Later Development}

By the time five chaetigerous segments have been delimited, the larva is rather over I mm. in length and is about a month old. The gut becomes further elaborated, the jaws growing in size and becoming armed with an increasing number of teeth. The palps grow rapidly, and the tentacles and cirri of the head region together with the anal cirri grow steadily. By this time coelomic spaces are clearly visible between the gut and the body wall, and masses of rounded cells, presumably the first coelomic corpuscles, may be seen tumbling about in the coelom with the movements of the larvae.

Larvae with six, nine and nineteen chaetigerous segments are shown in Text-fig. 6, from which it will be seen that septa become externally visible when about seventeen or eighteen segments have been formed. By the time 


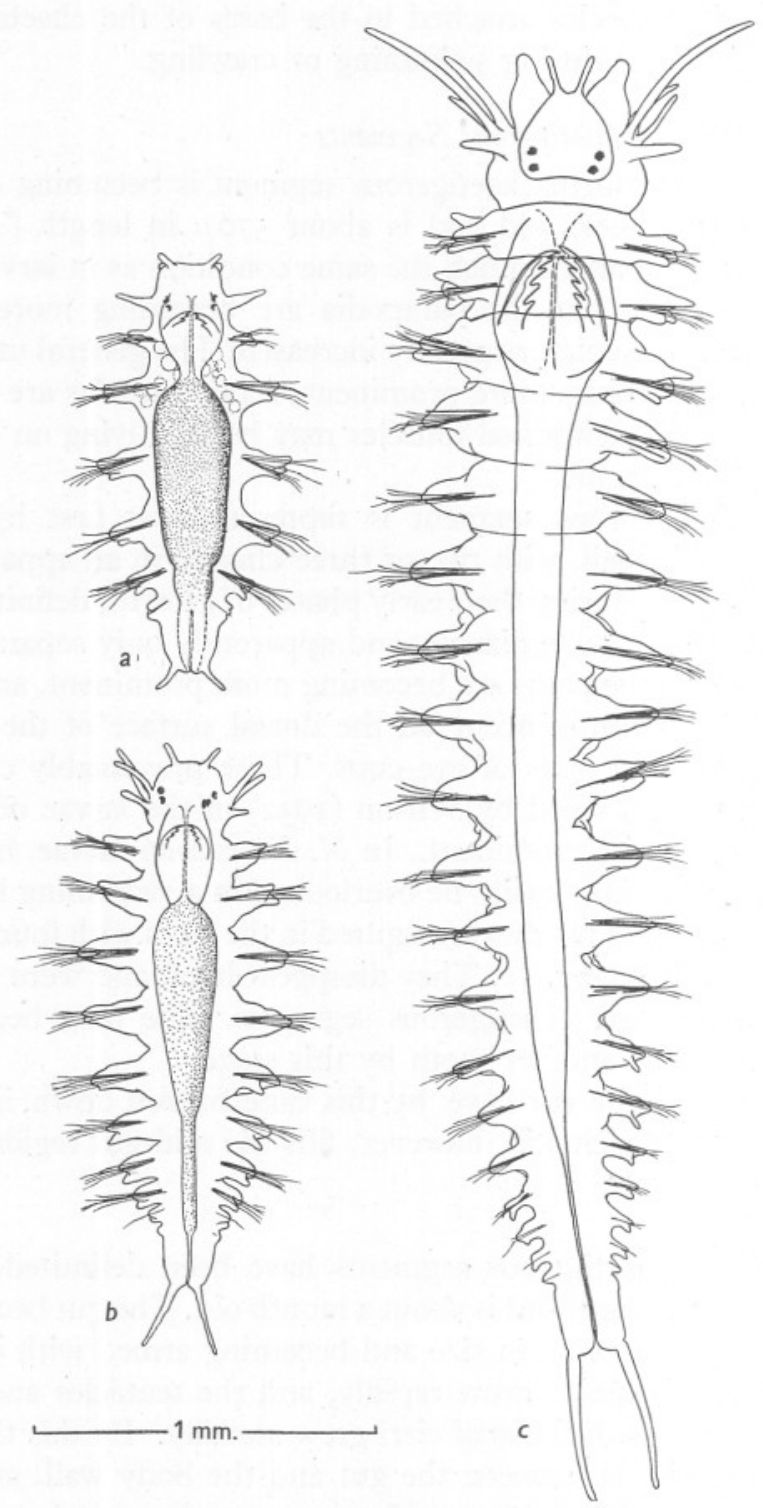

Text-fig. 6. $a$, larva with six chaetigerous segments, about $5^{\frac{1}{2}}$ weeks old (dorsal view); $b$, larva with nine chaetigerous segments, about 7 weeks old (dorsal view); $c$, young worm with nineteen chaetigerous segments, about ro weeks old (dorsal view). 
this last stage (Text-fig. $6 c$ ) has been reached, the young worm, which is by then between 2.5 and $3.0 \mathrm{~mm}$. long, is still quite colourless, but orange pigment appears in the anterior dorsal region soon afterwards, and in the larvae with nineteen chaetigerous segments the dorsal blood vessel may be clearly seen as a deep red mid-dorsal line. By now the adult mode of life has been assumed, and the larva is virtually a miniature adult, burrowing in the mud.

\section{Development of the faws and Chaetae}

As already mentioned, jaws appear in the pharyngeal region of the larva with three chaetigerous segments. They are at first simple transparent structures and only later become toothed (Text-fig. 7). One tooth (apart from the apex of the jaw which is not considered as a 'tooth' in this description) has developed by the time the larval stage with four chaetigerous segments has been reached, and further teeth are then added until, by the time that six chaetigerous segments have been formed, five teeth are borne on each jaw. Up to this stage the jaws remain more or less transparent, and the details could be made out only in larvae fixed in benzyl alcohol. By the time that five teeth have been formed, however, the jaws are beginning to harden and assume the amber colour characteristic of those of the adult. This change corresponds with the commencement of feeding, though the buccal region does not appear to be eversible until a rather later stage. A young worm with eighteen chaetigerous segments (about $3.2 \mathrm{~mm}$. long) was observed on one occasion to evert its proboscis, but this was never observed in larvae or young worms smaller than this. Paragnaths are not developed until much later.

Larval chaetae follow a succession similar in many ways to that described by Wilson (1932) in the larvae of $N$. pelagica. Homogomph spinigers predominate in both neuro- and notopodia during the early stages, with very few simple capillaries. Homogomph chaetae in $N$. diversicolor larvae have the tip turned over very slightly (Text-fig. 8). Larvae with three chaetigerous segments have, on the average, about five chaetae in each notopodium and four or five in each neuropodium. Usually there are slightly more chaetae in the notopodia than in the neuropodia. Wilson described $N$. pelagica larvae with three chaetigerous segments as having between seven and ten chaetae in each group, which is almost twice that of $N$. diversicolor. It is interesting to note in this connexion that Wilson's larvae were essentially pelagic, whereas those of $N$. diversicolor are typically bottom forms. Again, capillaries seem to be commoner in $N$. pelagica larvae than in the $N$. diversicolor larvae described in the present paper. Wilson also describes homogomph falcigers from $N$. pelagica larvae with three chaetigerous segments, but these are absent in the corresponding stage in $N$. diversicolor, though intermediate forms between homogomph spinigers and falcigers occur in slightly later larvae. All the compound chaetae have the distal parts closely toothed with long fine teeth. Heterogomph falcigers appear in later larvae, and by the time that the larva has acquired 
eighteen segments heterogomph falcigers predominate in the first few segments, but in the more posterior segments homogomph bristles still remain more numerous. Young worms with thirty chaetigerous segments have a predominating number of heterogomph falcigers, but a few homogomph spinigers remain, mainly in the notopodia. This condition approaches that of the adult.
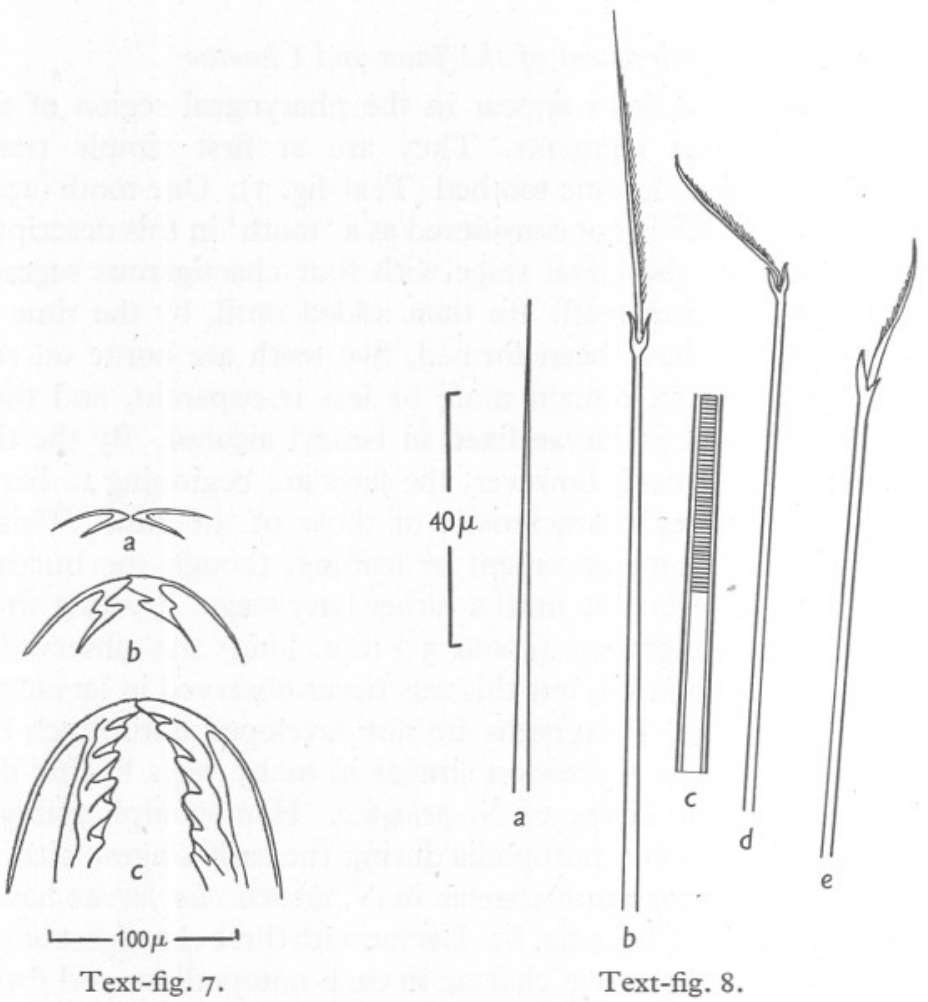

Text-fig. 7. Jaws from larvae with: $a$, three; $b$, four; $c$, six, chaetigerous segments.

Text-fig. 8. Larval chaetae. $a$, simple capillary; $b$, homogomph spiniger; $c$, fine structure of chaetae (base only); $d$, homogomph falciger; $e$, heterogomph falciger.

Apart from Wilson's close analysis of the succession of the larval bristles of $N$. pelagica, and some previous work on the same species by Herpin (I925), the development of the larval chaetae has not been closely studied. The only other detailed drawing of a larval chaeta of $N$. diversicolor known in the literature, is the drawing of a single chaeta by Hofker (I930). This author based his identification of his larvae partly on the resemblance of these chaetae to those of the adult, but it does not resemble the chaetae here described. Further, it should be noted that the larval chaetae in the very early larvae do not closely resemble those of the adult, either in character or composition. 
Aciculae occur first in larvae with ten chaetigerous segments, and after this stage has been passed, develop with the chaetae as the new segments are added. The formation of the acicula is not, therefore, initiated when the parapodia attain a certain age or size after the formation of the chaetae, the two sets of structures arising concurrently after the formation of about ten chaetigerous segments. It would seem to be some function of the size or age of the larva itself, rather than that of the individual parapodium. Typical larval chaetae are shown in Text-fig. 8 .

\section{Elaboration of the Parapodia}

The formation of the parapodium is of interest since its form in the adult, like that of the chaetae, is of taxonomic importance. In $N$. diversicolor the adult form is not approached by any of the parapodia until thirty or forty chaetigerous segments have been formed, and even then the older parapodia are by no means identical with those of the adult.

In very early larvae with three chaetigerous segments there are virtually no parapodia, but by the end of this stage simple notopodial and neuropodial lobes are recognizable (Text-fig. 9a). In larvae with four chaetigerous segments these two main lobes each begin to be divided into two main parts and the ventral cirri are plainly visible (Text-fig. $9 b$ ). This pattern persists over much of the strictly larval life and is much the same in larvae with ten chaetigerous segments, though the two main lobes are then much longer and supported by acicula. In a young worm with thirty-one chaetigerous segments notopodial and neuropodial lobes conform mainly to the adult plan (Textfig. $9 e$ ). By this time the dorsal cirri have also appeared and the noto- and neuropodia are composed of three subsidiary lobes, which are not, however, as distinctly separated as in the adult (Text-fig. $9 f$ ).

It is interesting that the ventral cirrus develops first, and that the development of the dorsal cirrus is delayed until the adult life has been assumed.

For more details of the development of the parapodia reference should be made to the work of Finke (1936).

\section{Development of the Head Region}

The larva with three chaetigerous segments possesses two pairs of tentaclelike processes on the head (Text-fig. Ioa). The anterior pair are always the shorter of the two, and represent the future prostomial tentacles. The posterior pair represent the first pair of peristomial cirri. Palps do not appear until the larva possesses four chaetigerous segments. Only one pair of peristomial cirri is present in larvae with seven chaetigerous segments, but by the time that a further two chaetigerous segments have been added, three pairs are recognizable. The full complement of four pairs is not developed till the larva 
possesses about sixteen chaetigerous segments. The first two pairs of peristomial cirri are derived from the first segment, while the two pairs which are

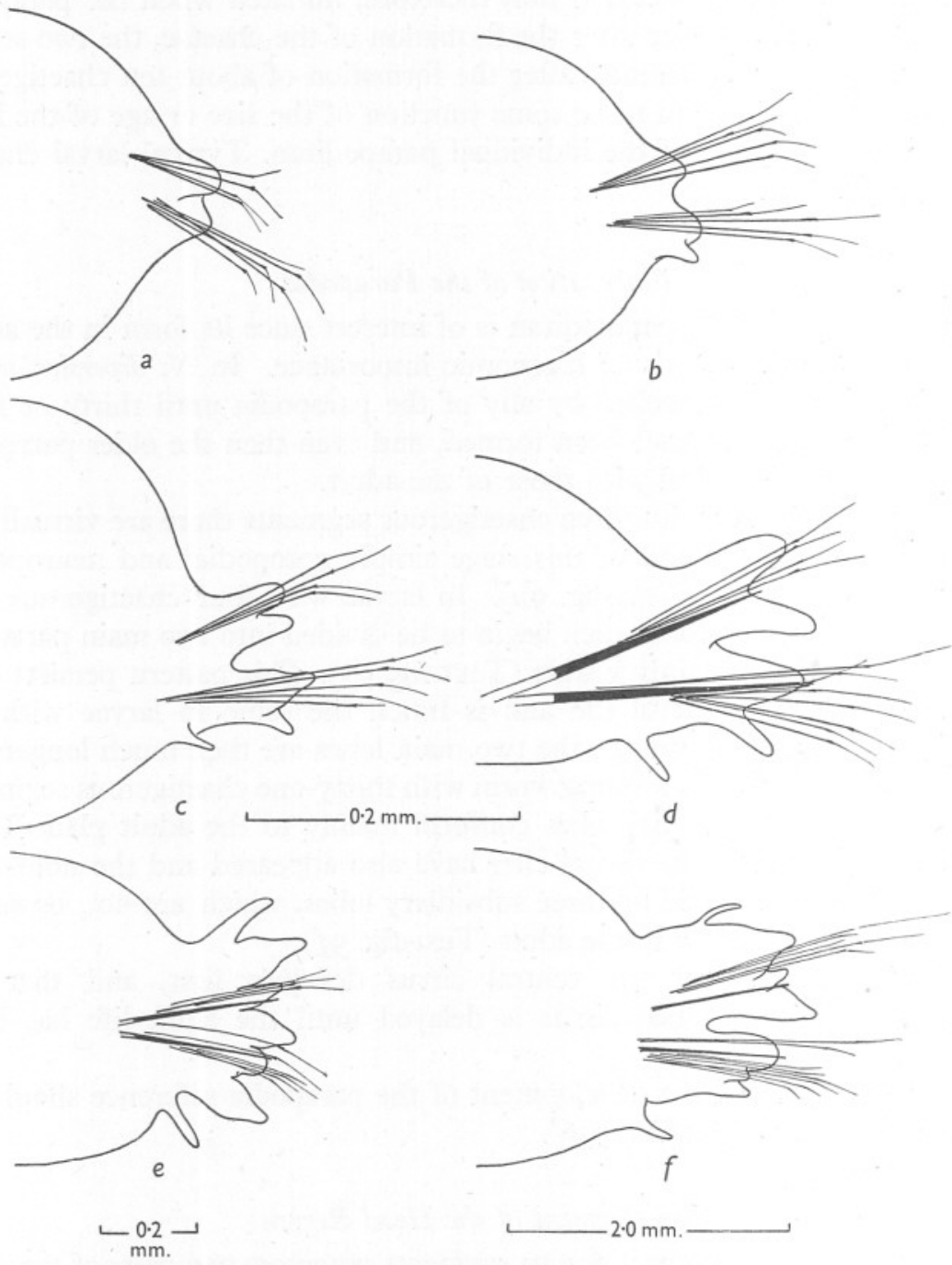

Text-fig. 9. $a$, second parapodium of a larva with three chaetigerous segments; $b$, second parapodium of a larva with four chaetigerous segments; $c$, fourth parapodium of a larva with five chaetigerous segments; $d$, fourth parapodium of a larva with ten chaetigerous segments; $e$, tenth parapodium of a young worm with thirty-one chaetigerous segments; $f$, parapodium of adult in mid-body region. $a, b, c$ and $d$ are to the same scale.

added later are derived from the first larval chaetigerous segment which coalesces with the first segment to form the peristomium or 'buccal segment' of the adult (see Table III). A similar mode of development was found by 
Hempelmann (I9II) in Platynereis dumerilii, and by Herpin (I925) in other nereids.

The prostomium is not distinctly separated off by a groove until the young worm has about eighteen chaetigerous segments, when the palps are becoming elaborated into the two parts characteristic of the adult (Text-fig. Iod).
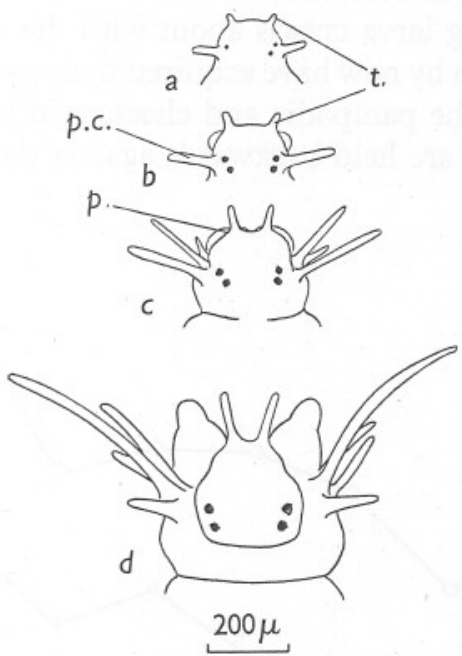

Text-fig. Io. Development of head region: $a$, head of young larva with three chaetigerous segments; $b$, head of larva with seven chaetigerous segments; $c$, head of larva with nine chaetigerous segments; $d$, head of larva with eighteen chaetigerous segments; $t$, prostomial tentacles; $p$, palp; p.c., peristomial cirri.

\section{Table III. Development of the Head Region}

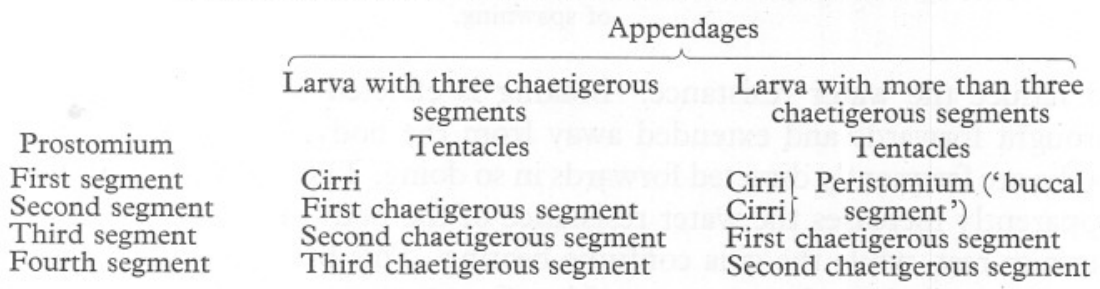

\section{LaRVAL Habits and Life History}

The young ciliated monotrochophores are weak swimmers and never continue swimming for any length of time, frequently coming to rest on the bottom. They are somewhat denser than sea water, and in nature these swimming movements cannot be of much importance in distributing the species. Young chaetigerous larvae cannot, at first, move their chaetae, but by the end of the larval stage with three chaetigerous segments the chaetal sacs have acquired a good musculature and can be moved backwards and forwards in the 
horizontal plane. By this stage, therefore, the larva can crawl on the substratum or on the walls of the parent burrow. Cilia are prominent, however, even in larvae with five or six chaetigerous segments, and in larvae with four chaetigerous segments (Text-fig. 5 c) the prototroch and subsidiary ciliary bands are still sufficiently well developed to enable the larva to swim off the bottom. Swimming is never continued for more than a few seconds at a time, and for the most part the young larva crawls about with the aid of the anterior three pairs of parapodia which by now have acquired their own intrinsic musculature.

During swimming, the parapodia and chaetae (in larvae with three or four chaetigerous segments) are held backwards against the sides of the body so as

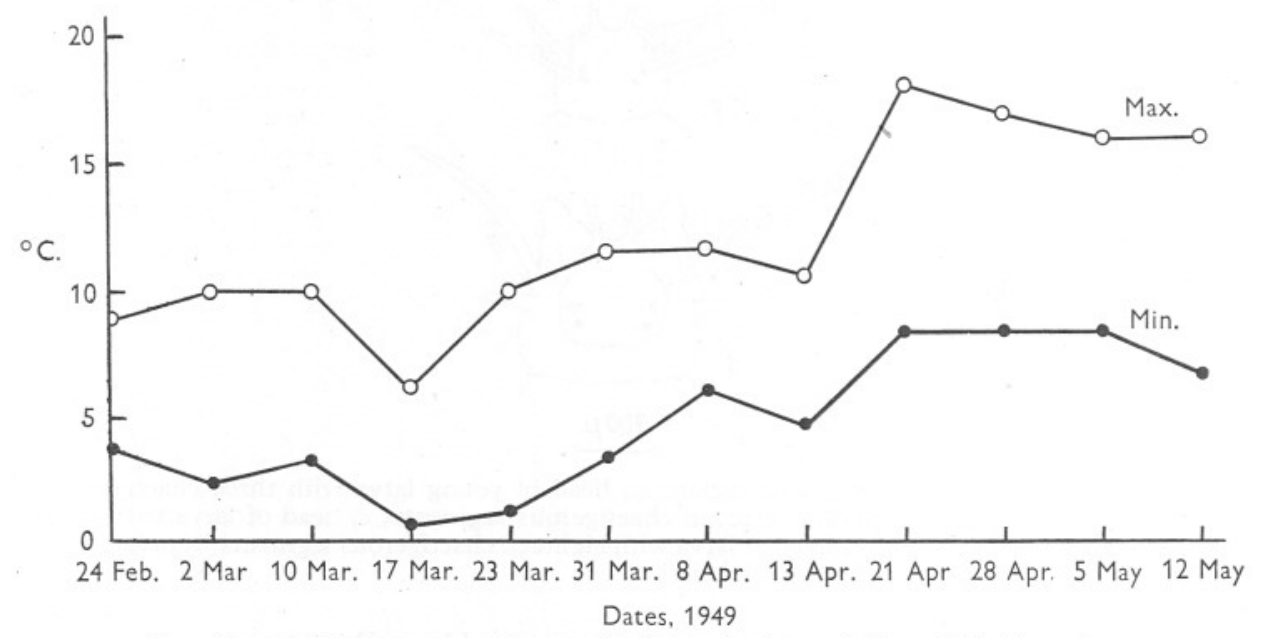

Text-fig. II. Temperature of natural habitat during early larval life from time of spawning.

to reduce the water resistance. Braking is effected by the parapodia being brought forwards and extended away from the body. The first pair of parapodia are frequently directed forwards in so doing. This action of the parapodia apparently increases the water resistance of the body sufficiently to bring the larva to rest, while the cilia continue beating. This braking action also brings the parapodia into the correct position for crawling to begin again, and with fairly active larvae such crawling and swimming periods alternate.

The larvae are not, however, particularly active until about ten chaetigerous segments have been delimited. Up to this stage the larva is apparently entirely lecithotrophic, but as feeding begins at about this time (when the larva is some 7 weeks old) it is probable that this assumption of a more active life is correlated with the beginning of active feeding. Probably little distribution of larvae occurs until this time. In one instance a burrow was opened which was swarming with scores of larvae with eight and nine chaetigerous segments, and it is highly probable that these larvae resulted from a successful 
fertilization in the burrow, or that the fertilized eggs had been washed into the burrow from the surface. The greatly increased activity of the larvae with ten chaetigerous segments coupled with the search for food probably serves to distribute the species, although distribution probably takes place mainly in later life.

Young worms with about twenty chaetigerous segments, and about $4 \mathrm{~mm}$. in length, if placed in a deep dish with a layer of fresh mud, promptly burrow into the mud and construct minute $U$-shaped tubes the openings of which are only 2 or $3 \mathrm{~mm}$. apart. These burrows may be seen in nature under favourable conditions.

The larvae are, therefore, typically bottom-living. Many authors, however, have ascribed larvae found in the plankton to Nereis diversicolor (Hofker, I930; Smidt, I944; Thorson, I946), but all workers seem to be agreed that they do not really represent pelagic forms but are bottom larvae which have

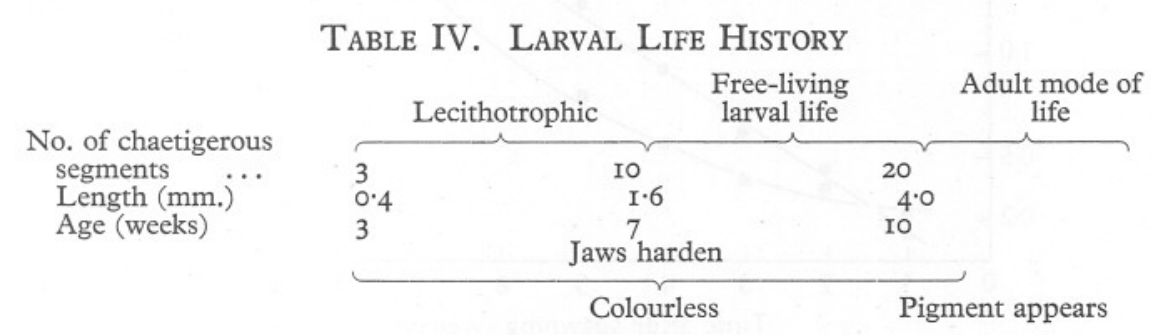

been carried up to the surface. Spärck (I926) found that young adult $N$. diversicolor appeared in cement tanks constructed during the summer in Nykøbing Mors (Limfjord) and these could only have developed from young worms or larvae swept off the bottom by currents.

The early larval life history is summarized in Table IV.

\section{GROWTH OF THE LARVAE}

Growth in the length of the larvae continued at a constant geometric rate over the early stages. The length of time elapsing between fertilization and the formation of the monotrochophore, the earliest stage collected in any appreciable numbers from the mud, was determined from the time taken for eggs in artificial fertilizations to reach this stage. The rate of growth of all the later stages was calculated from measurements of larvae obtained from the natural habitat. Collections were made every 3 days at first, and later, at weekly intervals, and all the larvae and young worms so obtained were measured. There was little size variation at first, but this became progressively greater, as would be expected, in later samples. The relative numbers of larvae in each stage were determined during the first month after the main spawning period and the frequency distributions of these samples arranged as a series of histograms in Text-fig. 2 (p. 334). Text-fig. I2 represents the rate of growth 
of larvae, constructed from the mean length calculated from the measurements of several dozen larvae in each stage. The curve will be seen to follow the

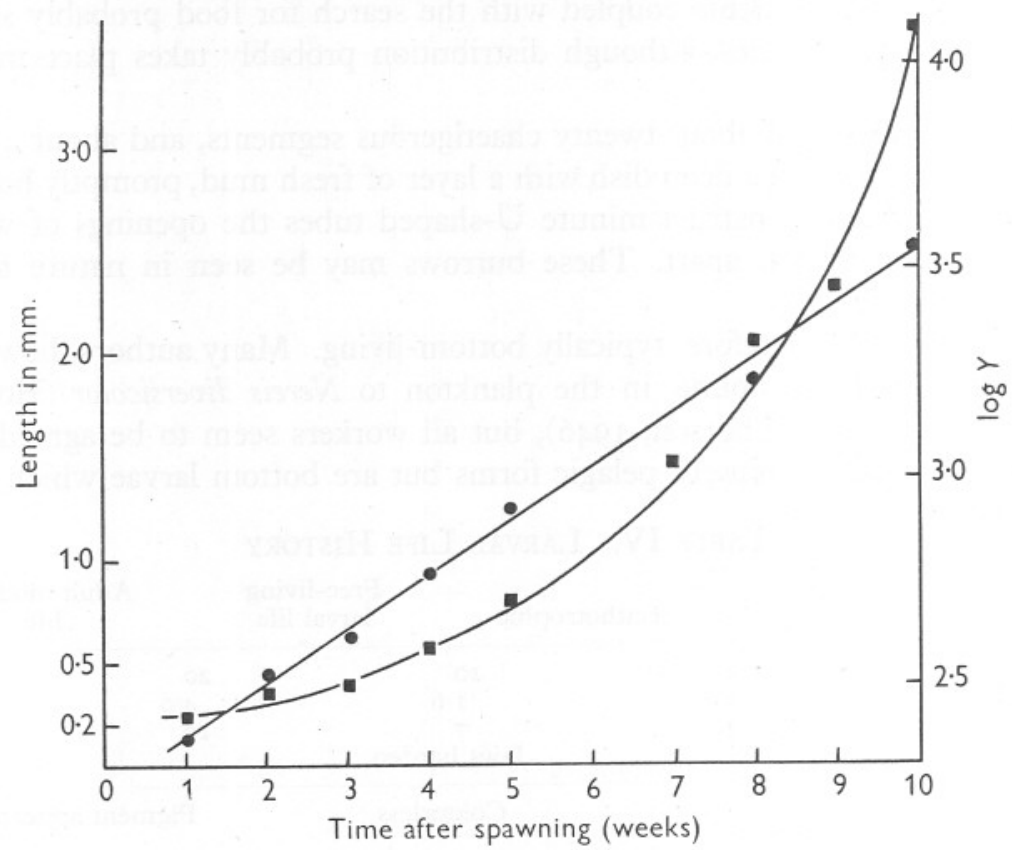

Text-fig. I2. Growth of larvae during first Io weeks.

\section{Table V. Growth of Larvae}

No. of chaetigerous segments

Egg to monotrochophore

Young chaetigerous larvae

Larvae with three chaetigerous segments

\begin{tabular}{|c|c|c|}
\hline '? & " & four \\
\hline צ & , & five \\
\hline " & , & six \\
\hline " & " & seven \\
\hline " & " & eight \\
\hline " & " & nine \\
\hline " & " & \\
\hline , & , & eleven \\
\hline " & פ & twelve \\
\hline " & " & thirteen \\
\hline " & " & fourteen \\
\hline " & " & fifteen \\
\hline ” & " & sixteen \\
\hline$"$ & " & seventeen \\
\hline "' & ” & ineteen \\
\hline " & " & \\
\hline
\end{tabular}

$$
\text { Length (mm.) }
$$$$
0.220
$$$$
0.330
$$$$
0.400
$$$$
0.570
$$$$
0.800
$$$$
0.950
$$$$
\text { I. I } 20
$$$$
\begin{aligned}
& I \cdot 120 \\
& I \cdot 480
\end{aligned}
$$$$
\text { I. } 700
$$$$
2 \cdot 050
$$$$
\text { - }
$$$$
\frac{-}{\bar{E}} \overline{-}
$$

Age (weeks after fertilization)

$$
\begin{array}{r}
\text { I-2 } \\
2 \\
3 \\
4 \\
\frac{5}{6} \\
\frac{7}{7} \\
\frac{8}{-} \\
\hline 9 \\
\hline- \\
\hline
\end{array}
$$

normal logarithmic pattern characteristic of growth with a constant geometric growth rate. This growth rate (geometric, multiplicative, or instantaneous) was calculated, basing the calculations on larvae from I to 9 weeks in age, and 
was found to be 0.04277 . Details of these calculations are given in the Appendix (p. 360).

The length, age, and corresponding number of chaetigerous segments of larvae obtained from the natural habitat is summarized in Table V. During the early stages there is a nearly perfect positive correlation between the total length and number of chaetigerous segments. The graph (Text-fig. I3) shows this relation in larvae up to the age of about Io weeks. Using the usual statistical methods (see Appendix) the calculation of the correlation coefficient ' $r$ ' based on twelve randomly selected larvae from each size-group and having

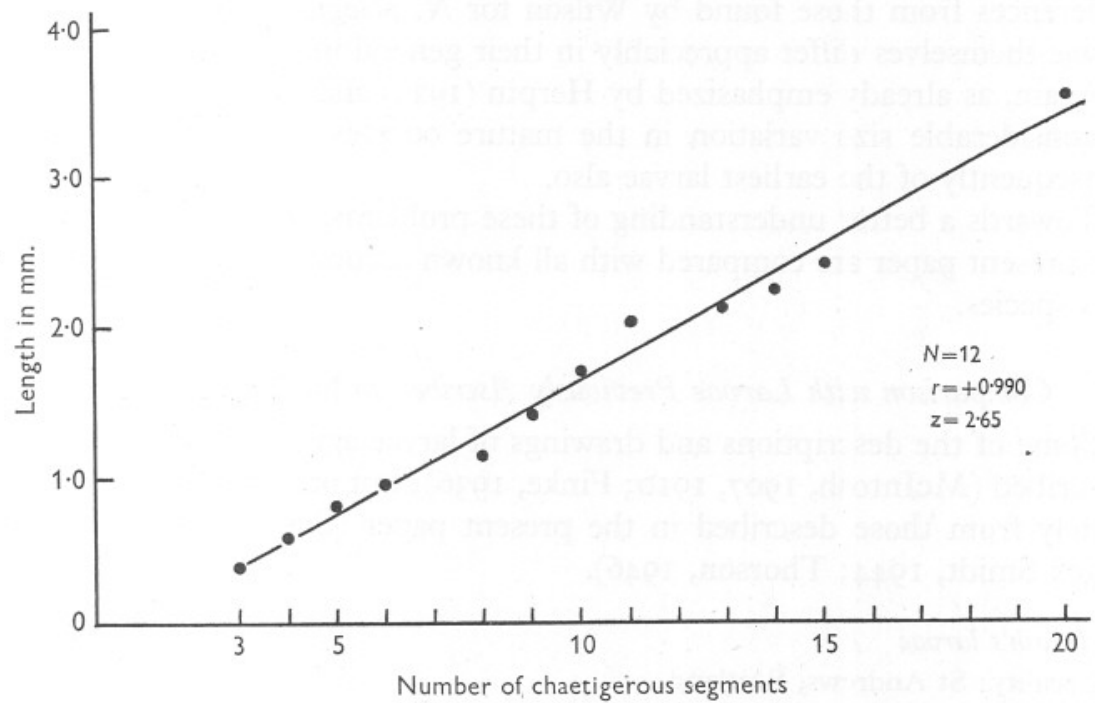

Text-fig. I3. Correlation between larval length and number of chaetigerous segments.

between three and twenty chaetigerous segments gave a value of ' $r$ ' as +0.9900 ; an almost perfect positive correlation. From this Fisher's term ' $z$ ' $=2 \cdot 65$. As the worms become older the degree of correlation becomes less, and in 'adult' worms the degree of correlation is too small to have any real significance.

\section{COMPARISON WITH OTHER AcCounts OF Nereid LARVAe}

Many species of Nereis are often found in the same habitat, and this has caused much confusion with regard to the identification of the larvae. Larvae found in the plankton have frequently been ascribed to $N$. diversicolor, solely on the basis that this species is the most abundant in that area. Difficulty in identifying nereid larvae is increased by their variability. Wilson (1932), for example, found certain differences between his $N$. pelagica larvae and those described by Herpin (1925); while the variation in reproduction and development of Platynereis dumerilii has been described by Hempelmann (I9II). 
A larva cannot therefore be ascribed to another species solely on the basis of slight anatomical differences from that of a known species. Conversely, under certain conditions, larvae of two species may appear remarkably similar; as for instance do Herpin's (1925) drawings of Perinereis cultrifera larvae and the Nereis diversicolor larvae described in the present paper. It would seem probable that the details of chaetae and chaetal succession would be highly specific. Although this may be so, it should be noted that the larval chaetae do not necessarily resemble those of the adult, and in the present investigation a careful study of the succession of larval chaetae did not reveal striking differences from those found by Wilson for $N$. pelagica larvae, although the larvae themselves differ appreciably in their general morphology.

Again, as already emphasized by Herpin (1925) and discussed above, there is considerable size variation in the mature oocytes of $N$. diversicolor, and consequently of the earliest larvae also.

Towards a better understanding of these problems, the larvae described in the present paper are compared with all known accounts of larvae ascribed to this species.

\section{Comparison with Larvae Previously Ascribed to Nereis diversicolor}

Some of the descriptions and drawings of larvae agree well with those here described (McIntosh, 1907, I910; Finke, 1936); but others differ more or less widely from those described in the present paper (Schultze, I856; Hofker, I930; Smidt, 1944; Thorson, I946).

\section{McIntosh's larvae}

Locality: St Andrews, Scotland.

Size: Not given (ripe oocyte given as O. I $524 \mathrm{~mm}$.).

Description (I9IO, figs. $7 \mathrm{I}-73$, p. 320 ; fig. 74, p. 322): Chalkwell larvae correspond well with McIntosh's figures, though these are not detailed. Degree of development of head appendages and anal cirri similar in larva with three chaetigerous segments (probably an early four-chaetigerous segmented larva) and in larva with six chaetigerous segments.

\section{Finke's larva}

Locality: Kiel.

Description (fig. I, p. 244): a larva with four chaetigerous segments closely similar to Chalkwell larvae.

\section{Schultz'es 'larvae'}

Locality: Frisches Haff; in the coelom.

Description: in no way resemble nereid larvae. Probably parasites.

\section{Hofker's larvae}

Locality: Zuidersee (plankton).

Size: small compared with Chalkwell larvae. Trochophore $\mathrm{I} 40 \mu$ (Chalkwell diversicolor larvae were $220 \mu$, and McIntosh's oocytes were little over $\mathrm{I} 50 \mu$.) 
Description (fig. I2 $a-d$, p. 200; fig. I3 $a-c$, p. 20I): previously discussed by Thorson (I946). Early trochophores differ in having well-marked apical tuft; similar in having well-marked prototroch but little or no telotroch. Smaller size. Chaeta figured does not resemble Chalkwell $N$. diversicolor larval chaetae; neither do the jaws from a larva with six chaetigerous segments.

Hofker based his identification on: (I) chaetae, which he regarded as resembling the adult; (2) most abundant adult in the area. Both these points have already been discussed. Hofker's chaeta is provided with large stout teeth, never observed in $N$. diversicolor larval chaetae from Chalkwell, in which the teeth were extremely fine.

\section{Smidt's larvae}

Locality: Copenhagen Harbour (plankton).

Size: small compared with Chalkwell larvae. Larva with four chaetigerous segments less than $350 \mu$ (Chalkwell $N$. diversicolor $600 \mu$ ). Larva with five chaetigerous segments $700 \mu$ (Chalkwell $800 \mu$ ).

Description (fig. 5, p. 254): larvae do not resemble Chalkwell $N$. diversicolor larvae, having three eye-cups on each side. Larva with four chaetigerous segments very small; five chaetigerous segmented larva relatively larger. In larva with four chaetigerous segments prostomial tentacles and peristomial cirri apparently not developed (well developed in Chalkwell larvae) though anal cirri roughly equivalent in length. Pigment (?) on head region in larva with five chaetigerous segments not seen in Chalkwell larvae.

\section{Thorson's larva}

Locality: Øresund.

Size: smaller than Chalkwell larvae. Larva with four chaetigerous segments c. $450 \mu$ (Chalkwell 550-600 $\mu$ ).

Description (fig. 30, p. 67): show some resemblance to Smidt's larvae. Unlike Chalkwell larvae-parapodial lobes well developed in larva with four chaetigerous segments, anal cirri much shorter and unlike those of Chalkwell larvae, three eye-spots. Thorson's discussion of this larva, as well as that of Hofker, should be consulted.

\section{Discussion}

Many of the interesting features in the reproduction of this nereid have already been discussed. The main points of interest remaining are the alleged occurrences of the phenomena of metamorphosis, hermaphroditism, viviparity, and parthenogenesis.

Metamorphosis. Most recent authorities (McIntosh, I907, I9I0; Fauvel, I923; Schröder, I886; Herpin, I925; Dehorne, I925) agree that $N$. diversicolor is normally atoquous. Other workers (Heinen, I9II; Thieren, I909) claim to have found epitoquous forms.

Heinen describes an epitoquous form which he regarded as $N$. diversicolor, but Herpin (I923, I925) regards this as a confusion of species, and points out that Heinen's figures might equally well refer to Neanthes succinea Leuck. Heinen's drawings of the parapodia correspond fairly closely with Fauvel's drawings (1923) of succinea, and also the length of the peristomial cirri in Heinen's drawings resemble those of succinea rather than those of diversicolor, in which they are much shorter. Heinen, however, records the occurrence of 
succinea as well, showing that he must have been aware of the similarity. Heinen regards Nereis diversicolor to be normally epitoquous and compares it with $N$. japonica (see Izuka, 1908). Heinen quotes Brandt and Riecke as also finding epitoquous forms at Kiel on two separate occasions.

The resemblance of the process of 'metamorphosis' described by Dehorne (1925) is only superficial, as previously pointed out by Herpin (1925). Fage (1924) and Fage \& Legendre (1923) do not mention N. diversicolor, and the heteronereids described by Sorby (1906) were not referred to this species.

Thieren (1909), on the other hand, agrees with Heinen, and also claims to have found an epitoquous stage. Herpin regards this, as in Heinen's instances, to have been a confusion of species.

Thomas (I930a) found that chaetae in mature females sometimes tended to degenerate and suggested that this might be interpreted as an aborted or rudimentary step towards metamorphosis to an epitoquous condition. The significance of histolysis in relation to this problem has already been discussed.

Epitoquous forms, if they do occur, are therefore certainly rare, and it is probable that those reported are not attributable to this species. It may be concluded that $N$. diversicolor is normally atoquous. Epitoquous forms have never been found by the writer, and although a careful examination of maturing worms has been made, no anatomical changes, other than those associated with histolysis and parenchyma formation, were observed.

Hermaphroditism. Mendthal's view (I889) that the species was hermaphrodite was based on the assumption that the pear-shaped bodies which were almost certainly the dorsal ciliated organs of Goodrich (1893, I945), were testes. He supported his argument by quoting Moquin-Tandon's discovery of an hermaphrodite nereid (N. massiliensis) in I869. This is not unique, since Johnson (1908) found the minute nereid Lycastis quadraticeps to be hermaphrodite, while Platynereis dumerilii also has an hermaphrodite form (Hempelmann, I9II). Mendthal concluded that, though the worm was hermaphrodite, the male gametes ripened before the ova. Gravier (1905) considered that hermaphroditism might occur exceptionally, but McIntosh doubts Mendthal's statements, and de St Joseph also could not corroborate these views. Herpin (I923 $a, 1925)$ and more recent workers agree in finding the species dioecious. This is in accordance with observations made by the writer.

Viviparity. Theoretically, ovoviviparity might result from (I) parthenogenetic development of the coelomic oocytes, (2) as a result of internal fertilization, or (3) self-fertilization in the existence of hermaphroditism.

This last explanation may be discounted, although it was suggested by some of the earlier workers.

The second suggestion is also unlikely to occur, in spite of the existence of a form of sexual congress. Schröder (I886), however, thought that the sperm entered via the nephridia to cause internal fertilization, and concluded that the species was viviparous after discovering 'morulae' in the coelom, though this 
observation was sceptically treated by McIntosh (1907, I9I0) since Schröder failed to find the larvae later in the year. These may have been abortive cleavage stages produced by abnormal conditions, or may even have been young sperm plates. Just (1915) found in the American N. limbata, that the oocytes would not fertilize in the tissue juices, and this may have some significance in relation to the present problem.

Parthenogenesis. This might occur in the coelom, or after spawning. The first hypothesis has already been considered, but a further observation may be added here. The discovery by the writer of several oocytes from which the 'fertilization' membranes had become lifted off, in the coeloms of unspawned females, not only supports the theories of Heilbrunn (1924) that the elevation of this membrane is due to a purely physical effect, but also suggests that it is not therefore impossible that cleavage stages might follow, and this would then concur with the views of Smidt (1944), Thorson (1946), and the observations of Schröder (I886).

Regarding the second hypothesis, viz. that the spawned eggs may develop parthenogenetically, Herpin (1923c, I925) obtained cleavage stages from the unfertilized oocytes owing to hypertonicity resulting from evaporation, or other peculiar conditions (Fischer, 1902, 1903; Dehorne, 1925; Herpin, 1925; Just, $1928 a, b)$.

Herpin noted that the gelatinous envelopes were not always developed in these artificial fertilizations, and the writer has also found them to be frequently absent in artificially fertilized eggs, and in naturally occurring stages. Segmentation was irregular (Herpin, I925), the cleavage stages being somewhat similar to those obtained artificially by Fischer (1902, 1903) from N. limbata, and to those obtained by the writer. For a general discussion of these topics reference should be made to the work by Morgan (1927).

Nereis eggs are very resistant to extreme environmental conditions, as is shown by experiments which have been performed on $N$. limbata (Just, I928 a, I930 $a, b$; Barron, 1932, etc.). The eggs of this species were found to be particularly resistant to lowered salinity and to temporary exposure to anaerobic conditions (Barron, 1932). No experiments have yet been performed on the eggs of $N$. diversicolor, though if the eggs and larvae of this species are similarly adapted to resist extreme conditions, as seems likely, then in this species this resistance may be regarded as having survival value. The relationship of breeding habits to salinity is being investigated.

\section{SUMMARY}

An account is given of the reproduction and development of the larva of $N$. diversicolor $\mathrm{O}$. F. Müller.

In any one population the number of males was found not to exceed 10 $\%$.

The species is dioecious. Both sexes become green at maturity, but may be distinguished externally. 
Ripe oocytes, which vary between 200 and $250 \mu$ in diameter mature in a loose coelomic parenchyma, and are released by rupture of the body wall after its partial histolysis. Sperm is released through the nephridia, or possibly by rupture of the body wall as well. In the male histolysis occurs, but the coelomic parenchyma is transitory. Sperm matures in the form of coelomic sperm plates.

Spawning was found to take place over a limited period centred in I949 round the third lunar quarter in February after a sharp rise in temperature. Spawning has been found to take place generally in early spring; variations are discussed. A form of sexual congress occurs.

Larvae develop in the mud, and there is no true pelagic phase.

Development is relatively slow. Cilia are not well developed in the larvae. The external morphology of the larva is discussed.

The young larvae become active when 7 weeks old, and the adult mode of life is assumed at Io weeks, when the worm is $4 \mathrm{~mm}$. in length.

The species is atoquous.

Parthenogenesis, hermaphroditism, and viviparity do not normally occur.

\section{REFERENCES}

Amirthalingham, C., I928. On lunar periodicity in reproduction of Pecten opercularis near Plymouth in I927-28. Fourn. Mar. Biol. Assoc. Vol. xv, pp. 605-4I.

BARRON, E. S. G., I932. The effect of anaerobiosis on the eggs and sperm of seaurchin, starfish, and Nereis and fertilization under anaerobic conditions. Biol. Bull. Woods Hole, Vol. 62, pp. 46-53.

Benham, W. B., I9Io. Polychaeta, in the Cambridge Natural History, Vol. II, pp. 239-344. London.

Claparìde, E., I868. Annélides chétopodes du Golfe de Neapel. Mém. Soc. Phys. Genève, T. xIx, p. 465.

Costello, D. P. \& Young, R. A., I939. The mechanism of membrane elevation on the egg of Nereis. Biol. Bull. Woods Hole, Vol. 77, p. 3II.

DeHorne, A., I922a. Histolyse et phagocytose musculaire dans le coelome des néréides à maturité sexuelle. C.R. Acad. Sci., Paris, T. CLxxiv, pp. I043-5.

- - I $922 b$. Destruction et phagocytose des fibres musculaires à la fin de la maturation des ovocytes chez Hediste diversicolor. C.R. Soc. Biol., Paris, T. LXXXVII, pp. I305-7.

- 1924. Marche générale des phénomènes de myolyse chez Hediste diversicolor pendant la maturation des ovocytes. C.R. Soc. Biol., Paris, T. xCI, pp. 303-4.

— 1925. Observations sur la biologie de Nereis diversicolor. C.R. Acad. Sci., Paris, T. CLXXX, pp. I44I-3.

FAGE, L., I924. Sur quelques néréidiens à métamorphose incomplète. Bull. Soc. Zool. Fr., T. XLIX, pp. 46-58.

FAGE, L. \& Legendre, R., I923. Rythmes lunaires de quelques néréidiens. C.R. Acad. Sci., Paris, T. CLxxvII, pp. 982-5.

Fauvel, P., I923. Polychètes errantes. Faune de France, Vol. v. 488 pp. Paris. 
FINKE, D., I936. Zur Formbildung der Parapodien von Nereis diversicolor O. F. Müller. Zool. Fahrb. Anat., Bd. 6I, pp. 239-342.

FISCHER, M. H., I902. Further experiments on artificial parthenogenesis in annelids. Amer. Fourn. Physiol., Vol. vil, pp. 30I-I4.

- 1903. Artificial parthenogenesis in Nereis. Amer. Fourn. Physiol., Vol. Ix, pp. 100-9.

Fox, H. MunRo, I932. Lunar periodicity in reproduction. Nature, Vol. 130, p. 23.

GALTSOFF, P. S., I940. Physiology of reproduction of Ostrea virginica. III. Stimulation of spawning in the male oyster. Biol. Bull. Woods Hole, Vol. 78, pp. II7-35.

GoodRICH, E. S., I893. On a new organ in the Lycoridea, and on the nephridium in Nereis diversicolor O. F. Müll. Quart. Fourn. Micr. Sci., Vol. 34, pp. 387-402.

- 1945. The study of nephridia and genital ducts since I895. Quart. Fourn. Micr. Sci., Vol. 86, pp. II 5-392.

Gravier, C., I905. Sur les néréidiens d'eau douce et leurs formes sexuées. Bull. Mus. Hist. Nat. Paris, T. XI, pp. 247-9.

—— I923a. La ponte et l'incubation chez les Annélides Polychètes. Ann. Sci. Nat. (Zool.), T. 6, pp. 153-247.

- 1923b. Remarques sur la note précédente de M. R. Herpin. C.R. Acad. Sci., Paris, T. ClXXvi, pp. 539-40.

Gravier, C. \& Dantan, J. L., I928. Sur quelques points de la biologie des annélides polychètes de la famille des néréidiens. C.R. Acad. Sci., Paris, T. I86, pp. I476-9.

HeIlbRunN, L. V., I924. The surface tension theory of membrane elevation. Biol. Bull. Woods Hole, Vol. 46, pp. 277-9.

Heinen, A., I9II. Die Nephthydeen und Lycorideen der Nord und Ostsee. Wiss. Meersuntersuch. Kiel, Bd. xIII, pp. I-87.

HempelmanN, F., I9II. Zur Naturgeschichte von Nereis dumerilii Aud. \& Edw. Zoologica, Stuttgart, Bd. 25, pp. I-135.

HeRPIN, R., I92I. Sur l'origine et le rôle des cellules à réserves de la cavité générale chez Perinereis cultrifera (Gr.) et Perinereis Marioni (Aud. et Edw.) et sur la différenciation précoce de leurs oeufs. C.R. Acad. Sci., Paris, T. CLxxin, pp. 249-52.

- I923a. Comparaison entre le comportement sexuel de quelques néréidiens des côtes de la Manche. C.R. Acad. Sci., Paris, T. clxxvi, pp. 536-9.

- I923b. Sur les relations sexuelles chez Perinereis cultrifera Grube. C.R. Acad. Sci., Paris, T. clxxvi, pp. 4I7-20.

- $1923 \mathrm{c}$. La ponte et le développement chez quelques néréidiens et syllidiens. C.R. Ass. Franc. Adv. Sci. Congrès de Bordeaux, 47e Session, pp. 558-62.

- 1925. Recherches biologiques sur la reproduction et le développement de quelques annélides polychètes. Bull. Soc. Sci. Nat. Ouest., Ser. 4, T. 5, pp. I-250.

HOFKER, J., I930. Faunistische Beobachtungen in der Zuidersee während der Trockenlegung. Z. Morphol. Ökol. Tiere, Bd. I8, pp. 189-216.

IzUKA, A., 1908. On the breeding habit and development of Nereis japonica n.sp. Annot. Zool. Fap. Vol. vi, pp. 295-305.

Johnson, H. P., I908. Lycastis quadraticeps, an hermaphrodite nereid with gigantic ova. Biol. Bull. Woods Hole, Vol, I4, pp. 37I-86.

Just, E. E., I915. Initiation of development in Nereis. Biol. Bull. Woods Hole, Vol. 28, pp. I-I8.

I $1928 a$. Hydration and dehydration in the living cell. I. The effect of extreme hypotony on the eggs of Nereis. Physiol. Zool., Vol. I, pp. I22-35.

- 1928b. Initiation of development in Arbacia. V. The effect of slowly evaporating sea water and its significance for the theory of autoparthenogenesis. Biol. Bull. Woods Hole, Vol. 55, pp. 358-68. 
JUst, E. E., I930a. Hydration and dehydration in the living cell. III. The fertilization capacity of Nereis eggs after exposure to hypotonic sea water. Protoplasma, Vol. Io, pp. 24-32.

- I930 b. Hydration and dehydration in the living cell. IV. Fertilization and development of Nereis eggs in dilute sea water. Protoplasma, Vol. Io, pp. 33-40.

- 1940. Egg-laying in Nereis diversicolor at Roscoff. Anat. Rec., Vol. 78, p. I3I.

KÜKENTHAL, W., I885. Über die lymphoiden Zellen der Anneliden. Fena Z. Naturw., Bd. xviII, pp. 3I9-64.

MacGinitie, G. E. \& MacGinitie, N., 1949. Natural History of Marine Animals. New York.

McIntosh, W. C., 1907. Notes from the Gatty Marine Laboratory, St Andrews, No. 28. On the reproduction of Nereis diversicolor O. F. Müller. Ann. Mag. Nat. Hist., Ser. 7, Vol. 20, pp. 176-85.

- I9IO. A monograph of the British annelids. Vol. II, Pt. II, pp. 233-524. Ray Soc. London.

Marine Biological Association, 1931. Plymouth Marine Fauna. (2nd ed.)

MendTHAL, M., I889. Untersuchungen über die Mollusken und Anneliden des Frisches Haffs. IV. Über die Geschlechtsverhältnisse der Nereis diversicolor. Schr. phys-ökon. Ges. Königsberg, Bd. xxx, pp. 27-42.

MOQUIN-TANDON, I869. Note sur une nouvelle annélide chètopode hermaphrodite. Ann. Sci. Nat., T. xI, pp. I34.

MoRgan, T. H., I927. Experimental Embryology. 757 pp. New York.

Newell, G. E., I948. A contribution to our knowledge of the life history of Arenicola marina L. Fourn. Mar. Biol. Assoc., Vol. xxvII, pp. 554-80.

- 1949. The later larval life of Arenicola marina L. Fourn. Mar. Biol. Assoc., Vol. xxviII, pp. 635-9.

ORton, J. H., I920. Sea-temperature, breeding and distribution in marine animals. Fourn. Mar. Biol. Assoc., Vol. xII, pp. 339-66.

Romieu, M., r92r $a$. Sur les éléocytes de Perinereis cultrifera (Grube). C.R. Acad. Sci., Paris, T. cLxxiII, pp. 246-9.

- I92I $b$. Observations cytologiques sur les leucocytes de Perinereis cultrifera. C.R. Ass. Anat. I6e réunion Paris.

St Joseph, DE, 1906. Les Annélides Polychètes des côtes de France (Océan et côtes de Provence). Ann. Sci. Nat., 9 sér., T. 3, pp. I45-260.

SCHNEIDER, K. C., I902. Lehrbuch der vergleichenden Histologie der Tiere. Jena.

SCHRÖDER, G., I886. Anatomisch-histologische Untersuchungen von Nereis diversicolor O. F. Müller. Zool. Inst. Kiel, Inaug. Diss., 43 pp.

SchUlTZE, M., I856. Ueber die Entwickelung von Arenicola piscatorum nebst Bemerkungen über die Entwickelung anderer Kiememwürmer. Abh. Naturf. Ges. Halle, Bd. III, pp. 213-33.

SMIDT, E. L. B., I944. Biological studies of the invertebrate fauna of the harbour of Copenhagen. Vidensk. Medd. Naturh. Foren. Kjøb., Vol. I07, pp. 235-316.

Sorby, H. C., I906. Notes on some species of Nereis in the district of the Thames estuary. Fourn. Linn. Soc. Zool., Vol. xxix, p. 434.

SPÄRCK, R., I926. On the food problem in relation to marine zoogeography. Physiol. Papers ded. to Prof. August Krogh.

ThamdRup, H. M., 1935. Beiträge zur Ökologie der Wattenfauna auf experimenteller Grundlage. Medd. Komm. Danmarks Fisk. Havund. Kjøbenhavn, Ser. Fiskeri, Bd. IO, I25 pp.

ThisREn, J., I909. Note éthologique relative à trois polychètes nouveaux pour la faune belge. Ann. Soc. R. Zool. Malac. Belg., T. xLIV, pp. II3-I9. 
Thomas, J. A., I930 $a$. Étude d'un processus néoplastique chez Nereis diversicolor O.F.M. dû à la dégénérescence des oocytes et quelquefois des soies. Arch. Anat. Micr., T. 26, pp. 252-333.

- I930 b. Sur les pigments vert et brun de Nereis diversicolor M. Bull. Soc. Zool. Fr., T. LV, pp. 97-IO3.

Thorson, G., I946. Reproduction and larval development of Danish marine bottom invertebrates. Medd. Komm. Danmarks Fisk. Havund. Kjobenhavn, Ser. Plankton, Bd. 4, No. I, 523 pp.

Townsend, G., I939. On the nature of the material elaborated by fertilizable Nereis eggs inducing spawning of the male. Biol. Bull. Woods Hole, Vol. 77, pp. 306-7.

WILSON, D. P., I932. The development of Nereis pelagica Linnaeus. Fourn. Mar. Biol. Assoc. Vol. xviII, pp. 203-I7.

WILson, E. B., I892. The cell-lineage of Nereis. Fourn. Morph., Vol. 6, pp. 36I-480. 


\section{APPENDIX}

\section{Table VI. Growth of Larvae}

Calculation of the geometric growth rate, based on larvae $\circ$ and 9 weeks after hatching, using the equation

$$
G=\frac{\log Y_{t}-\log Y_{0}}{0.4343 t},
$$

where $Y_{0}=$ length of larvae 0 week after hatching, $Y_{t}=$ length of larvae 9 weeks (63 days) after hatching, $t=63$ days. Then

$$
G=\frac{3 \cdot 54-2.37}{(0.4343) 63}=0.04277
$$

\section{Table VII. Growth of NeREIS DIVERSICOLOR LARVAE}

Correlation of length and number of chaetigerous segments.

No. of

chaetigerous

segments $(X)$

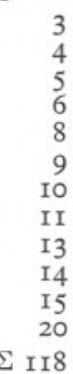

\section{Length}

$$
(\mathrm{mm} .)
$$

$(Y)$
0.40
0.57
0.80
0.95
$1 \cdot 12$
1.40
$1 \cdot 70$
2.05
$2 \cdot 10$
2.20
2.40
3.60
19.29

Calculation of the correlation coefficient ' $r$ '

$\begin{array}{ccc}d_{X} & d_{Y} & d_{X} d_{Y} \\ -6.83 & -\mathrm{I} .2 \mathrm{I} & 8.260 \\ -5.83 & -\mathrm{I} .04 & 6.063 \\ -4.83 & -0.8 \mathrm{I} & 3.912 \\ -3.83 & -0.66 & 2.527 \\ -\mathrm{I} .83 & -0.49 & 0.897 \\ -0.83 & -0.2 \mathrm{I} & 0.174 \\ +0.17 & +0.1 \mathrm{I} & 0.018 \\ +\mathrm{I} . \mathrm{I7} & +0.44 & 0.515 \\ +3 . \mathrm{I} & +0.49 & \mathrm{I} .553 \\ +4.17 & +0.59 & 2.460 \\ +5.17 & +0.79 & 4.084 \\ +\mathrm{IO} \cdot \mathrm{I7} & +\mathrm{I} \cdot 99 & 20.230 \\ - & - & 50.693\end{array}$

$d_{X}{ }^{2}$
$46 \cdot 650$
33.990
$23 \cdot 330$
$14 \cdot 670$
3.350
0.688
0.289
1.369
$10 \cdot 050$
17.390
$26 \cdot 730$
103.500
282.006

$d_{Y^{2}}$ $\mathrm{I} \cdot 464$ $\mathrm{I} \cdot 082$ 0.656 0.436 0.240 0.044 0.012 $0 \cdot 194$ 0.240 0.348 0.624 3.960 $9 \cdot 300$

Also

$$
\begin{aligned}
& N=\mathrm{I} 2, \quad M_{X}=9.83, \quad M_{Y}=\mathrm{I} \cdot 6 \mathrm{I} ; \text { and from above } \\
& \Sigma d_{X} d_{Y}=50.693, \quad \Sigma d_{X}^{2}=282.006, \quad \Sigma d_{Y}^{2}=9 \cdot 300 .
\end{aligned}
$$

Using the equation

$$
\begin{gathered}
r=\frac{\Sigma d_{X} d_{Y}}{\sqrt{\left(\Sigma d_{X}^{2} \Sigma d_{Y}^{2}\right)}}, \\
r=\frac{50.693}{\sqrt{(282.006 \times 9.300)}}=+0.9900
\end{gathered}
$$

From this, Fisher's term ' $z$ ' $=2 \cdot 65$.

\section{EXPLANATION OF PLATE I}

Fig. I. Transverse section of an almost mature female showing oocytes in the coelom and parapodial spaces. $\times 30$.

Fig. 2. Sperm plates in the coelom of an immature male. $\times$ I2O.

Fig. 3. Early stage in the growth of the oocytes: beginning of parenchyma formation. $\times 120$.

Fig. 4. Later stage in the growth of the oocytes: coelom filled with parenchyma. $\times$ I2O.

Fig. 5. Ripe oocytes: parenchyma breaking down into discrete cells. $\times$ I20.

Fig. 6. Living larva with four chaetigerous segments. $\times$ roo. 
Journ. MAR. BIol. Assoc. XXIX (2)

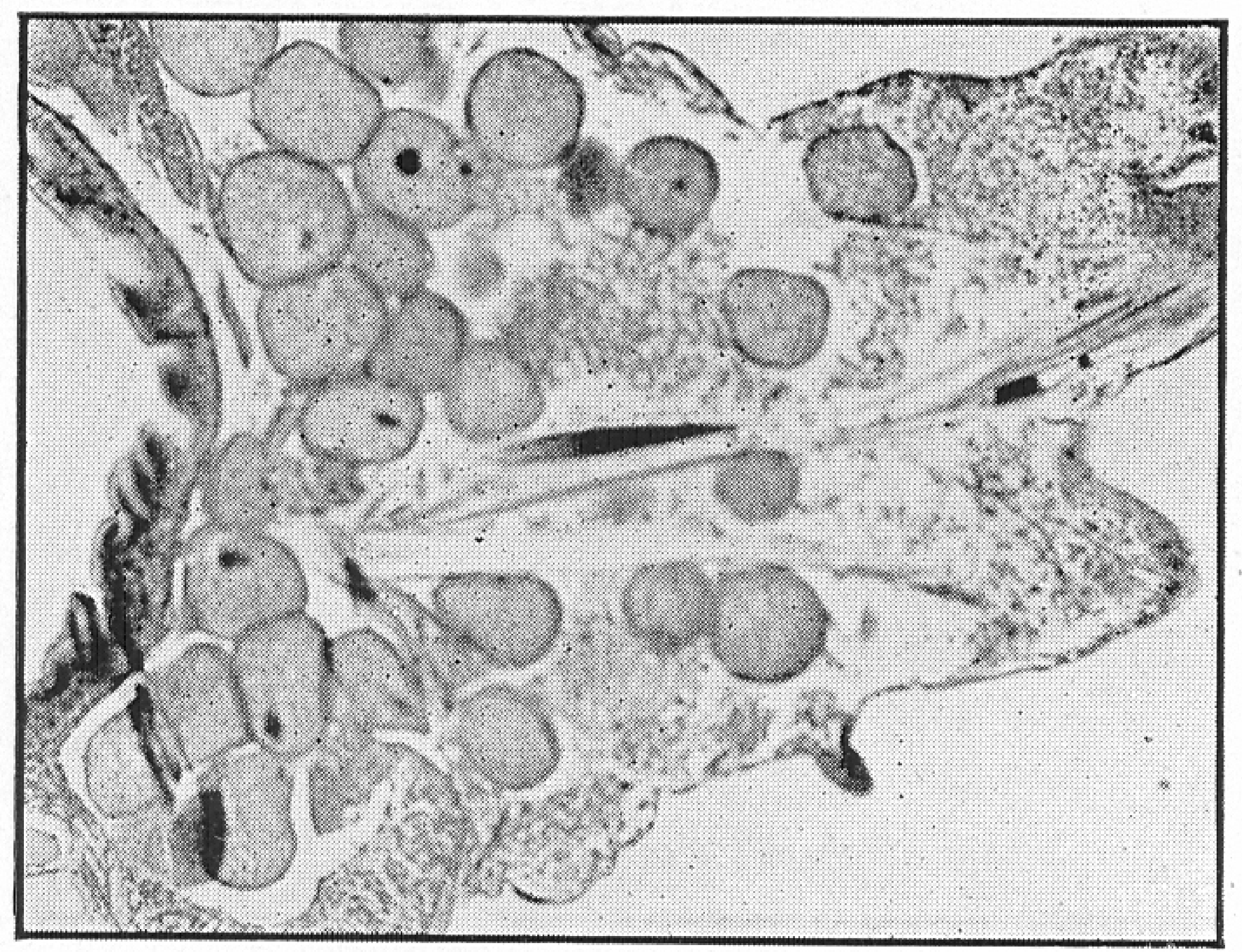

Fig. I.

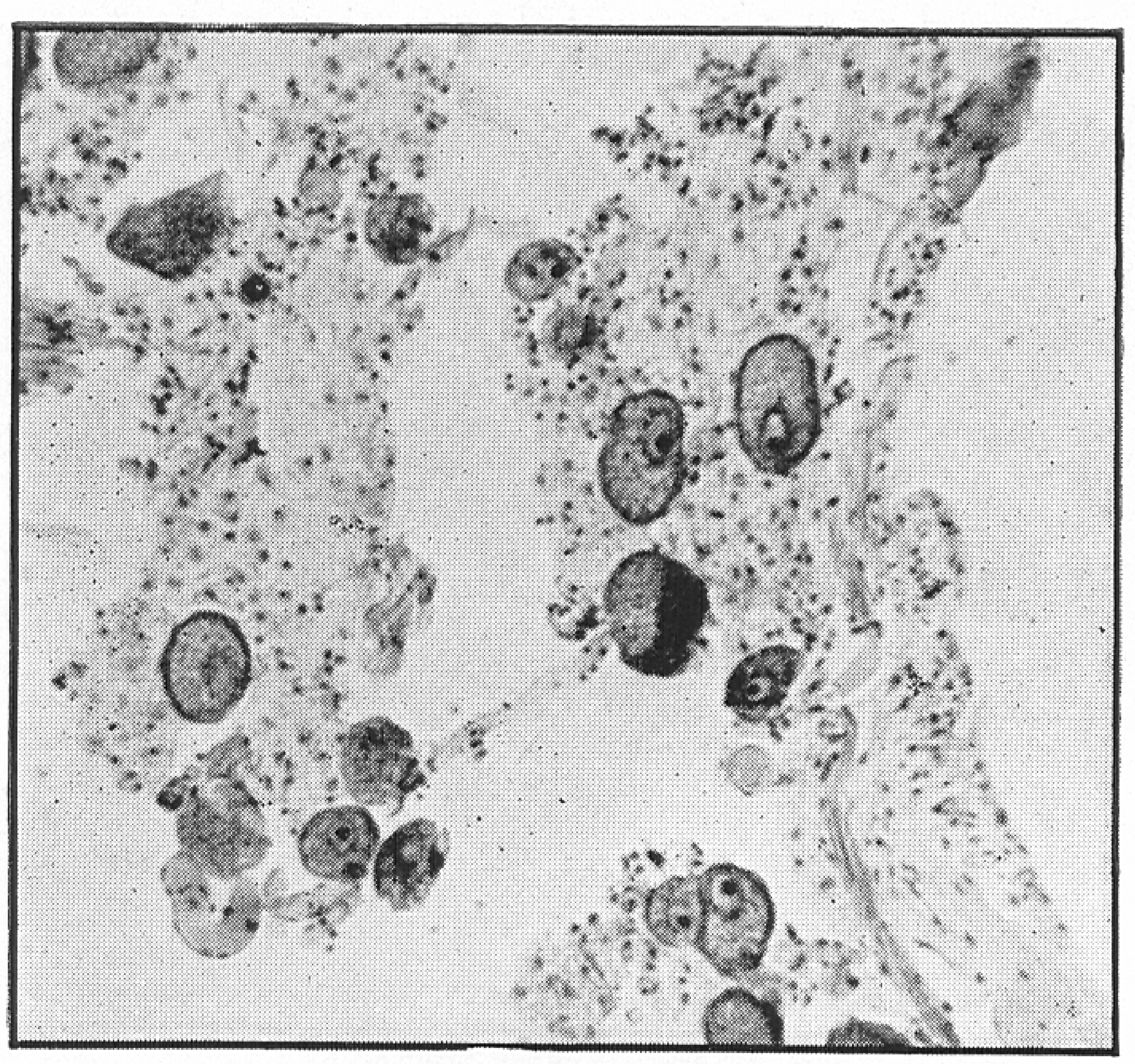

Fig. 3 .

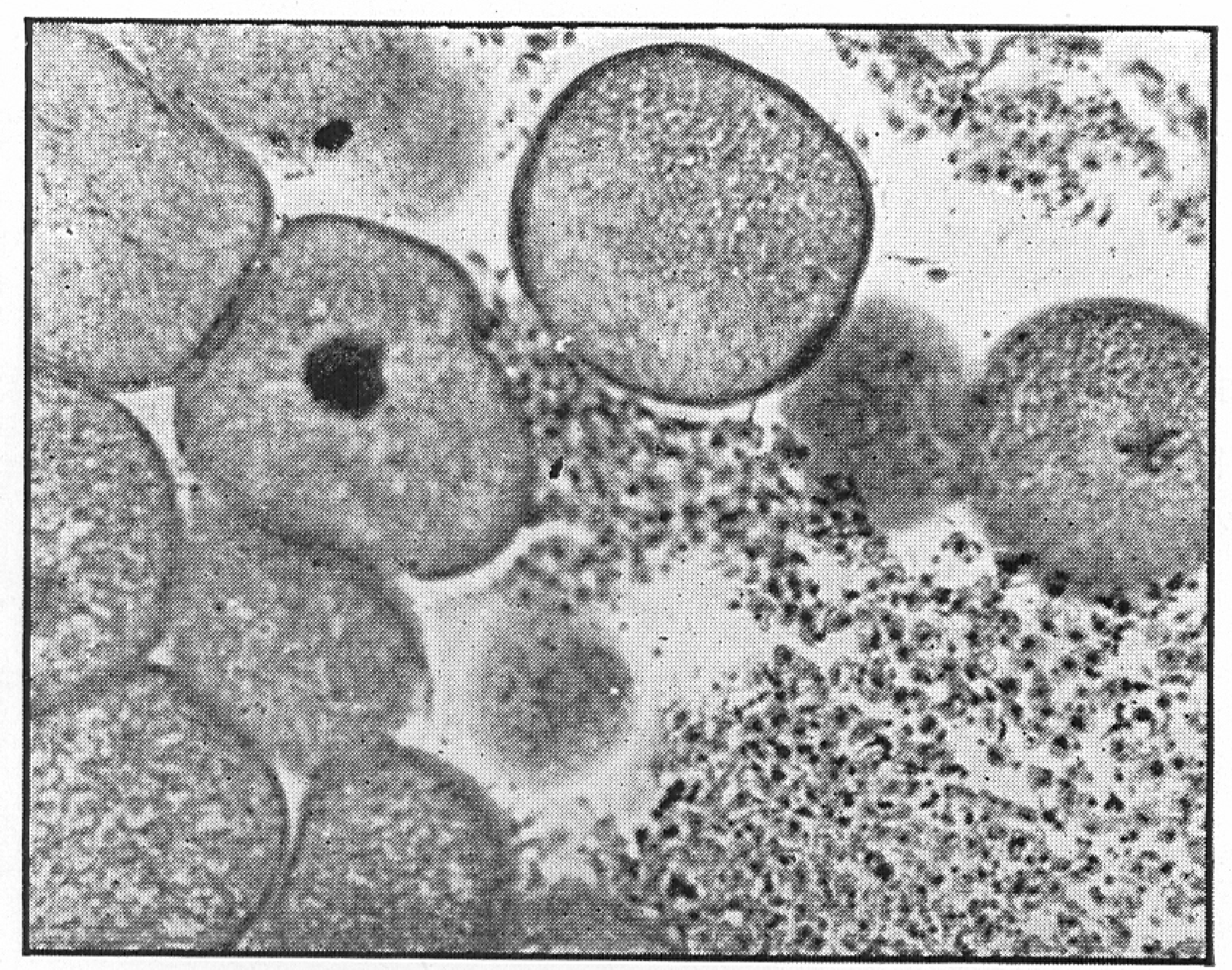

Fig. 5 .
DALES. PLATE I

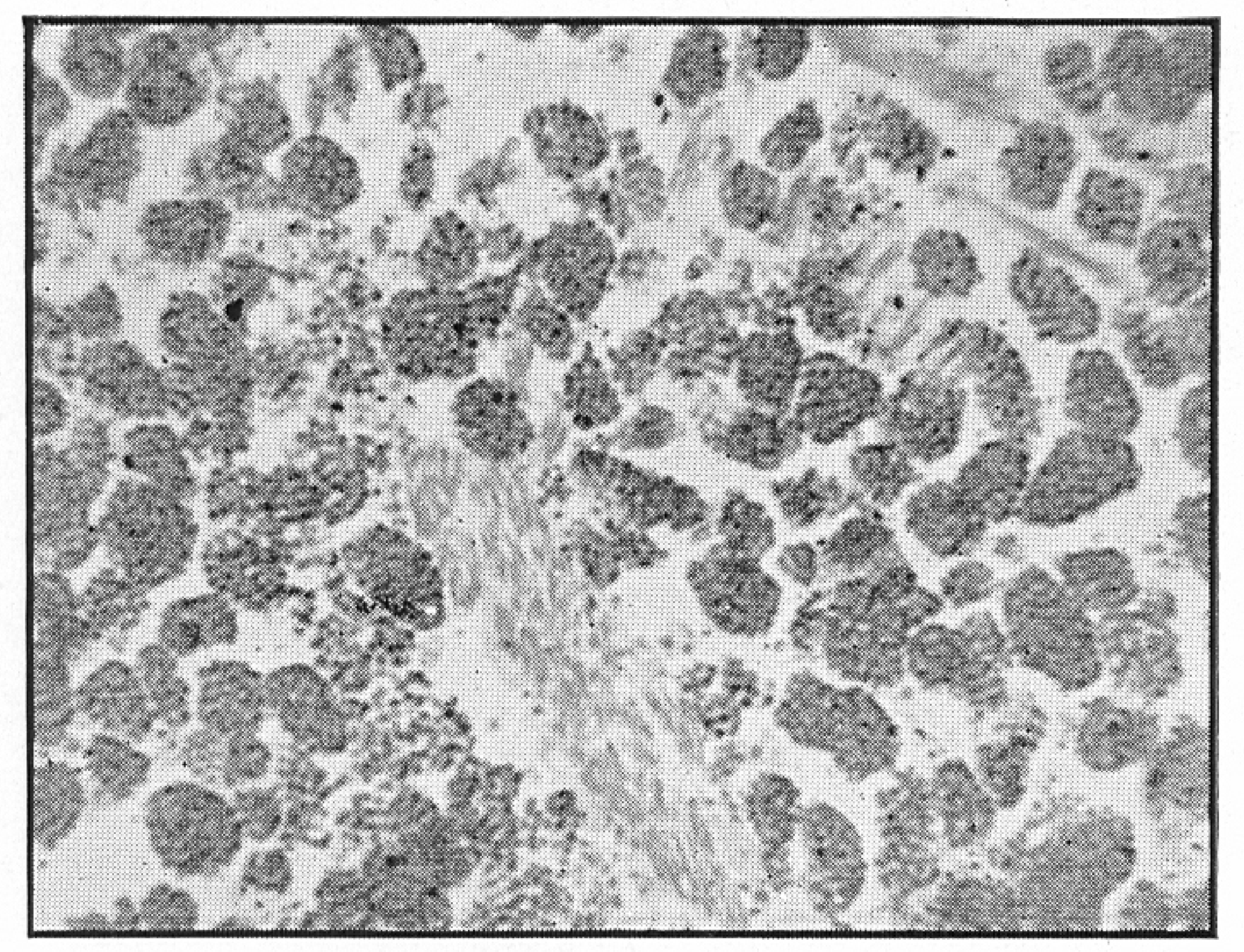

Fig. 2.

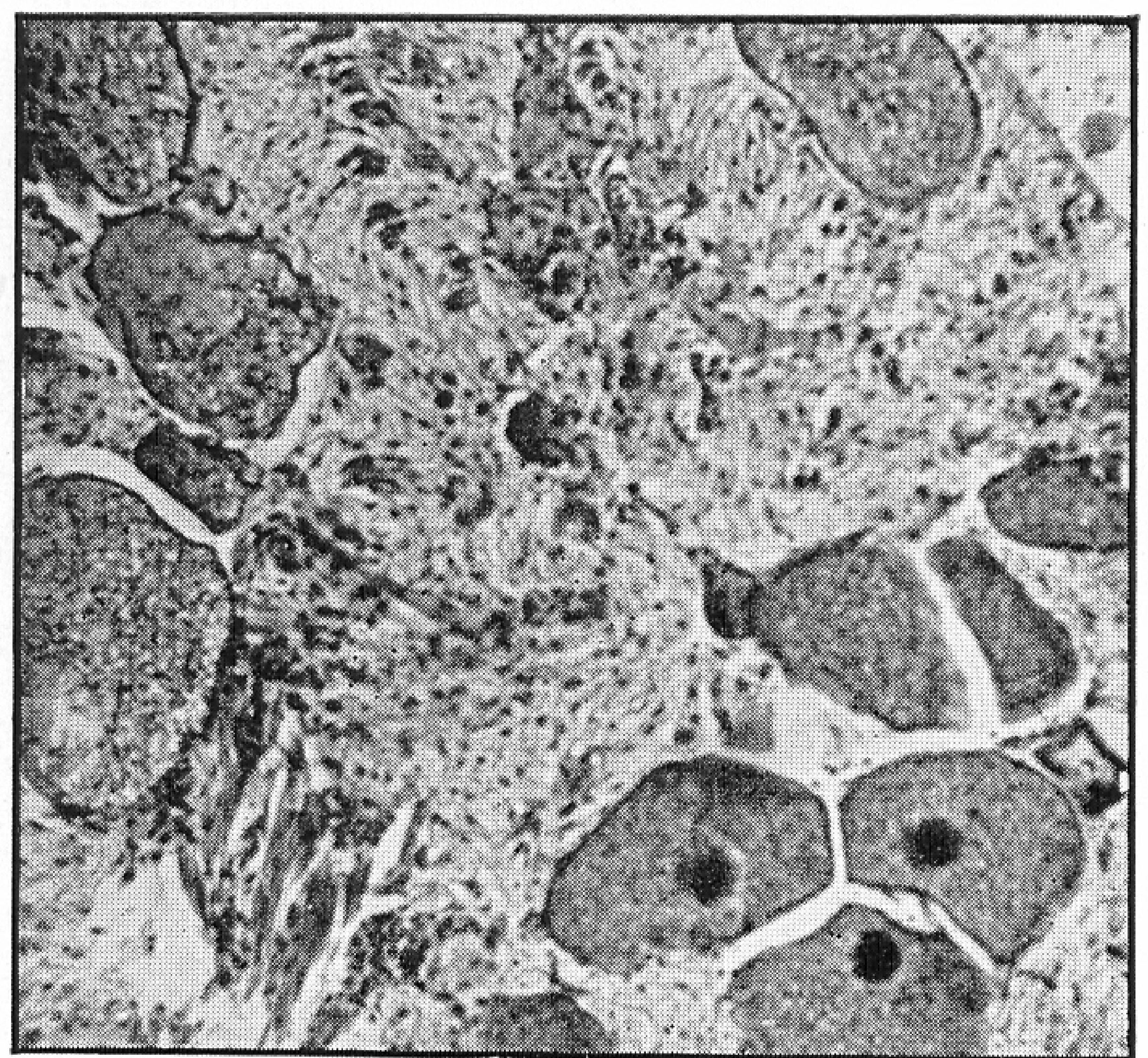

Fig. 4 .

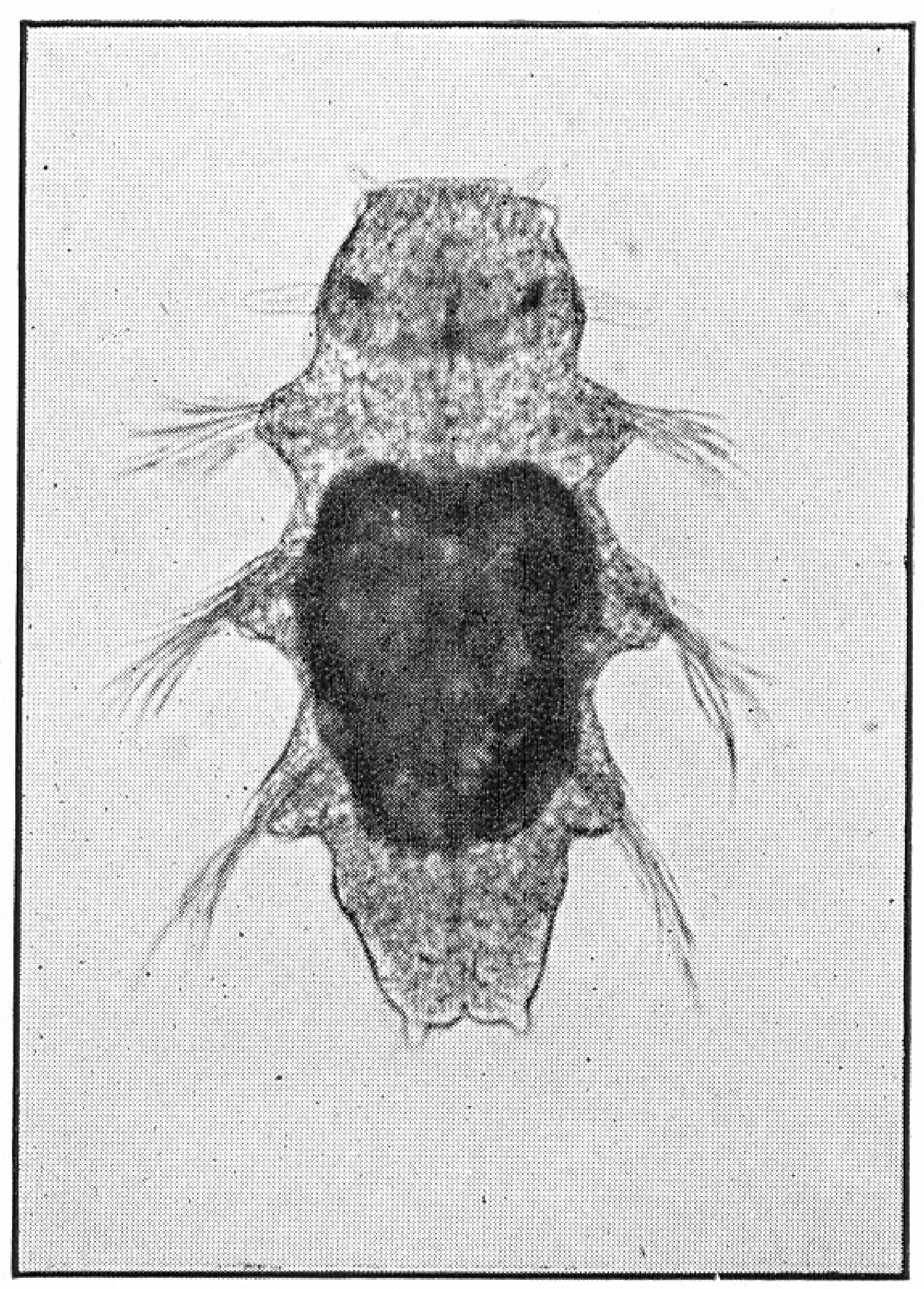

Fig. 6. 